\title{
The Qatar-South Fars Arch Development (Arabian Platform, Persian Gulf): Insights from Seismic Interpretation and Analogue Modelling
}

\author{
C.R. Perotti ${ }^{1}$, S. Carruba ${ }^{2}$, M. Rinaldi ${ }^{1}$, \\ G. Bertozzi ${ }^{2}$, L. Feltre ${ }^{2}$ and M. Rahimi ${ }^{3}$ \\ ${ }^{1}$ Dipartimento di Scienze della Terra, Università di Pavia, Pavia, \\ ${ }^{2}$ Edison S.p.A., Milano, \\ ${ }^{3}$ NIOC Exploration, 1st Dead End, Tehran \\ 1,2Italy \\ ${ }^{3}$ Iran
}

\section{Introduction}

The Qatar-South Fars Arch is a major regional anticline that runs through the central Persian Gulf (figure 1), warping the sedimentary cover of the Arabian Platform. The structure is detectable from offshore seismic data in the Iranian sector of the Persian Gulf, where it has a northeast-southwest direction, and extends southwards into the Qatar peninsula. Offshore, the arch hosts the biggest gas and condensate field in the world (South Pars-North Field), which straddles Iranian and Qatari waters. The Qatar-South Fars Arch represents a first-order structure and separates the Persian Gulf basin into two areas characterized by significant Proterozoic Hormuz salt diapirism (Northern and Southern Gulf Salt Basins, figure 1). The reported absence of salt-related phenomena on its crest led the authors to consider it as cored by an Infracambrian basement horst block, initiated during the Infracambrian Najd rifting, and repeatedly reactivated during subsequent geological time (Al-Husseini, 2000; Konert et al., 2001; Edgell, 1996; Talbot \& Alavi, 1996). Although basement tectonics in response to geodynamic events is considered the main cause of the deformations associated with basement-cored structures in the Arabian Platform, the development history of the Qatar-South Fars Arch may not fit neatly into this scenario. Its continuous growth and extension, which is about one order of magnitude greater than the other north-south trending "Arabian structures", the absence of major faults bounding the structure that actually encompasses several salt diapirs, and its northnortheast trend poorly matching with possible compressional and extensional reactivations that acted in a northeast-southwest direction point to a more complex origin for this intracratonic regional deformation.

In this paper, the interpretation of a grid of 2D seismic lines crossing the Qatar-South Fars Arch axis in the Iranian sector of the Central Persian Gulf allows the study of a regional geological section perpendicular to the arch and the reconstruction of a structural map of the area, with the aim of defining the deformation history of this structure. Considering the widespread and long-lasting Hormuz salt tectonics in the neighbourhood of the Qatar- 
South Fars Arch, we built scaled physical models in order to investigate the possible role of regional basal salt movements in the warping of the sedimentary succession over the structure, and to propose an alternative possible model of deformation of this intracratonic arch.

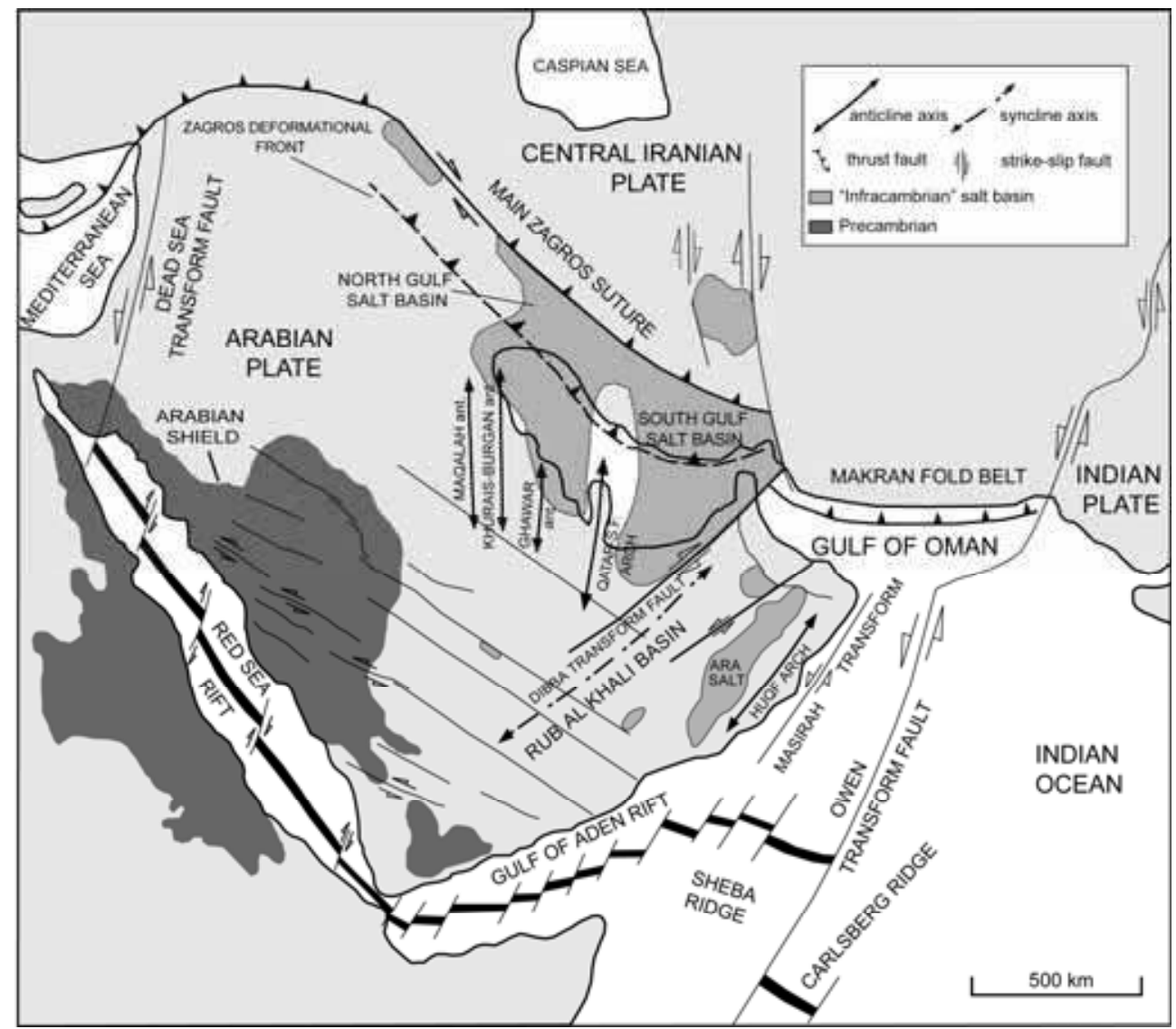

Fig. 1. Tectonic sketch map of the Persian Gulf and Arabian Peninsula, modified from AlHusseini (2000), Ziegler (2001) and Pollastro (2003)

\section{Geological setting and evolution of the Arabian Platform}

The Arabian Platform is a vast sedimentary basin where a very thick, virtually continuous sequence of sediments (figure 2) accumulated from the Late Proterozoic to Holocene on the northeastern margin of the Arabian sector of Gondwana (Alsharan \& Nairn, 1997; Beydoun, 1991; Edgell, 1996; Konert et al., 2001; Sharland et al,. 2001; Ziegler 2001). In a southwestnortheast section (figure 3), the basin is wedge-shaped with sediments gradually thickening from a few metres around the Arabian Shield (southwest), to about $18 \mathrm{~km}$ (Edgell, 1996) in the Zagros (northeast), which corresponds to the sector of the Arabian Platform deformed as a result of the Arabian-Iranian plate convergence in the Neogene. The present-day Zagros deformational front runs approximately along the Iranian coastline. 
The Qatar-South Fars Arch Development (Arabian Platform, Persian Gulf):

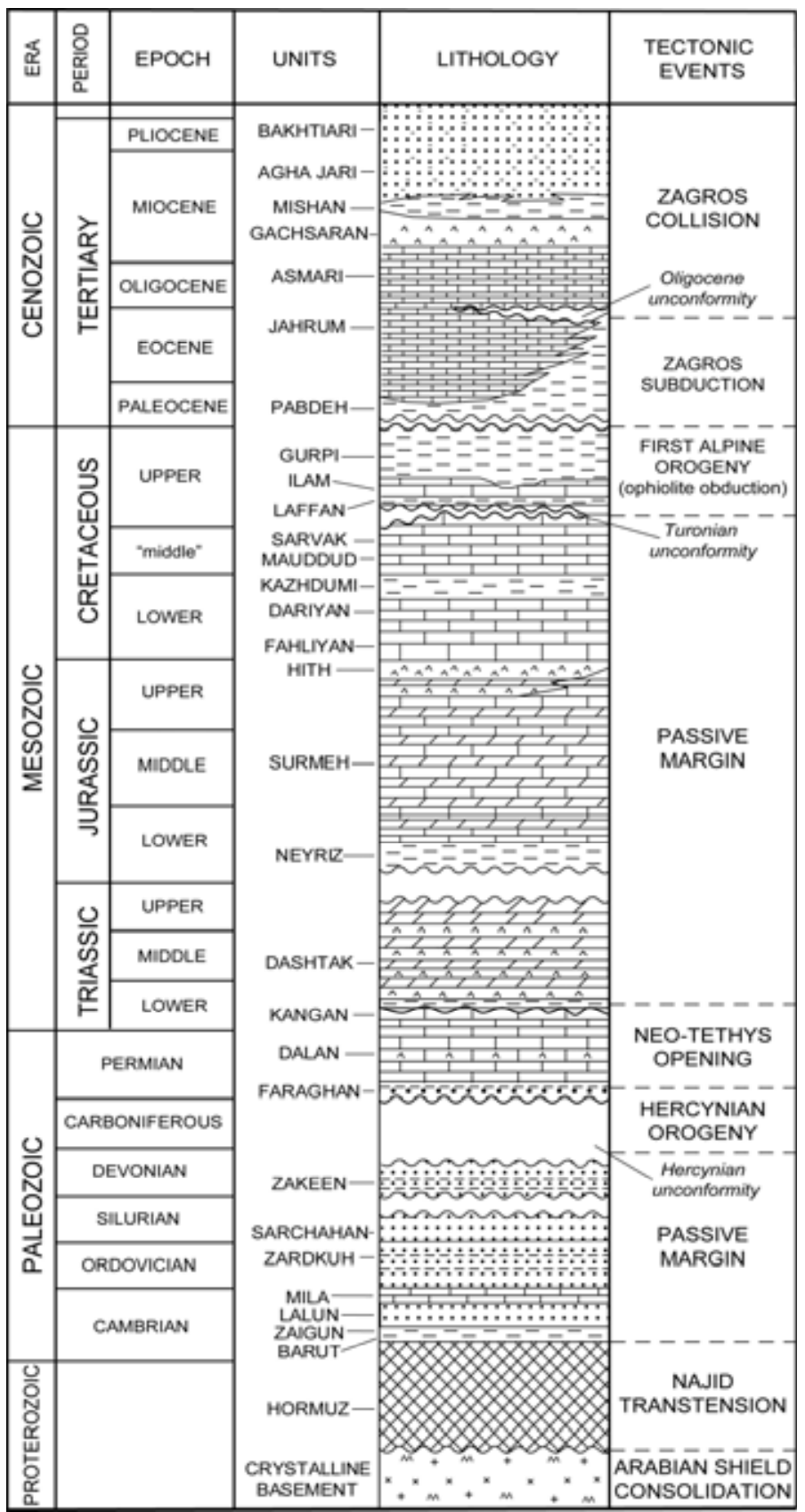

Fig. 2. Stratigraphic section, litho-stratigraphic units and major tectonic events of the central Persian Gulf, modified from Sharland et al. (2001) and Al-Husseini (2008) 


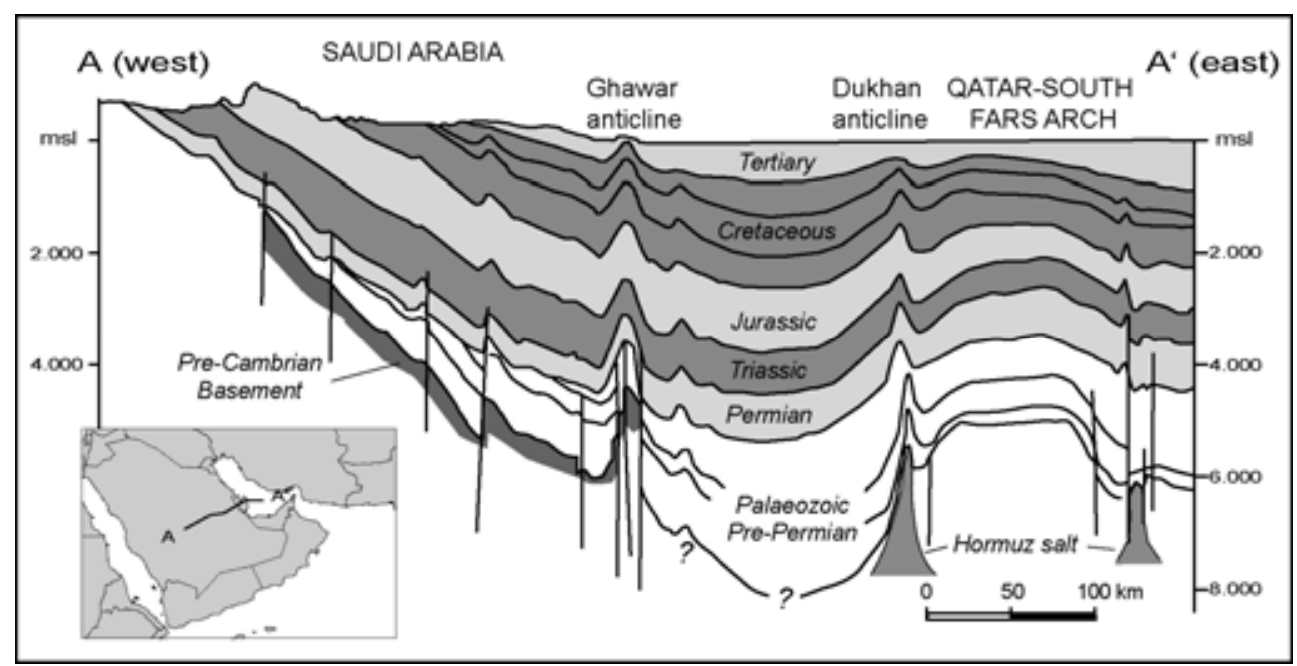

Fig. 3. Simplified geologic cross section across Saudi Arabia and Qatar from Arabian Shield to Arabian-Persian Gulf, modified from Alsharhan and Nairn (1997), Konert et al. (2001) and Pollastro (2003)

The geological history of the Arabian Platform (Alsharan \& Nairn, 1997; Konert et al., 2001; Sharland et al., 2001; Ziegler, 2001) can be summarized as follows (figure 4). After the consolidation of the Arabian Shield, a Late Proterozoic extensional phase (Najd rifting: Husseini, 1988; Al-Husseini, 2000) created a number of basins that are currently located in the Persian Gulf sector and in Oman, in which the thick (up to $2.5 \mathrm{~km}$ : Edgell, 1996) evaporites, predominantly composed of halite, of the Hormuz Formation (and the equivalent Ara formation in Oman) were deposited. The subsequent geological history of the area was characterized, during most of the Palaeozoic, by uniform clastic continental and shallow-marine sedimentation on a stable passive margin-interior margin setting on northeastern Gondwana. The Hercynian events of the Carboniferous affected the area, creating regional uplift, widespread erosion and basement tectonism along the inherited, mechanically weak Late Proterozoic trends (Konert et al., 2001). From the Permian to the Palaeogene the area was a broad, stable platform on the newly-formed passive margin at the northeastern border of the African plate, where the deposition of mainly shallow-water carbonates with minor anhydrites and shales occurred. The Neothethys Ocean to the northeast separated this margin from the Laurasia continental assemblage. In the Upper Cretaceous and then since the Oligocene, the northeastern part of the basin has been undergoing shortening as a consequence of collision of the Arabian Plate with Laurasia (Zagros orogeny). The resulting flexure of the Arabian Plate underneath the Zagros foldand-thrust belt created a wedge-shaped, low-angle (less than $2^{\circ}$ ) foreland basin, that has been the site of mixed evaporitic, carbonate and clastic sedimentation. Several regional unconformities and hiatuses punctuate the sedimentary succession as a consequence of eustatic sea-level changes and epeirogenic movements, most of them having occurred during plate-wide events (Sharland et al., 2001). 

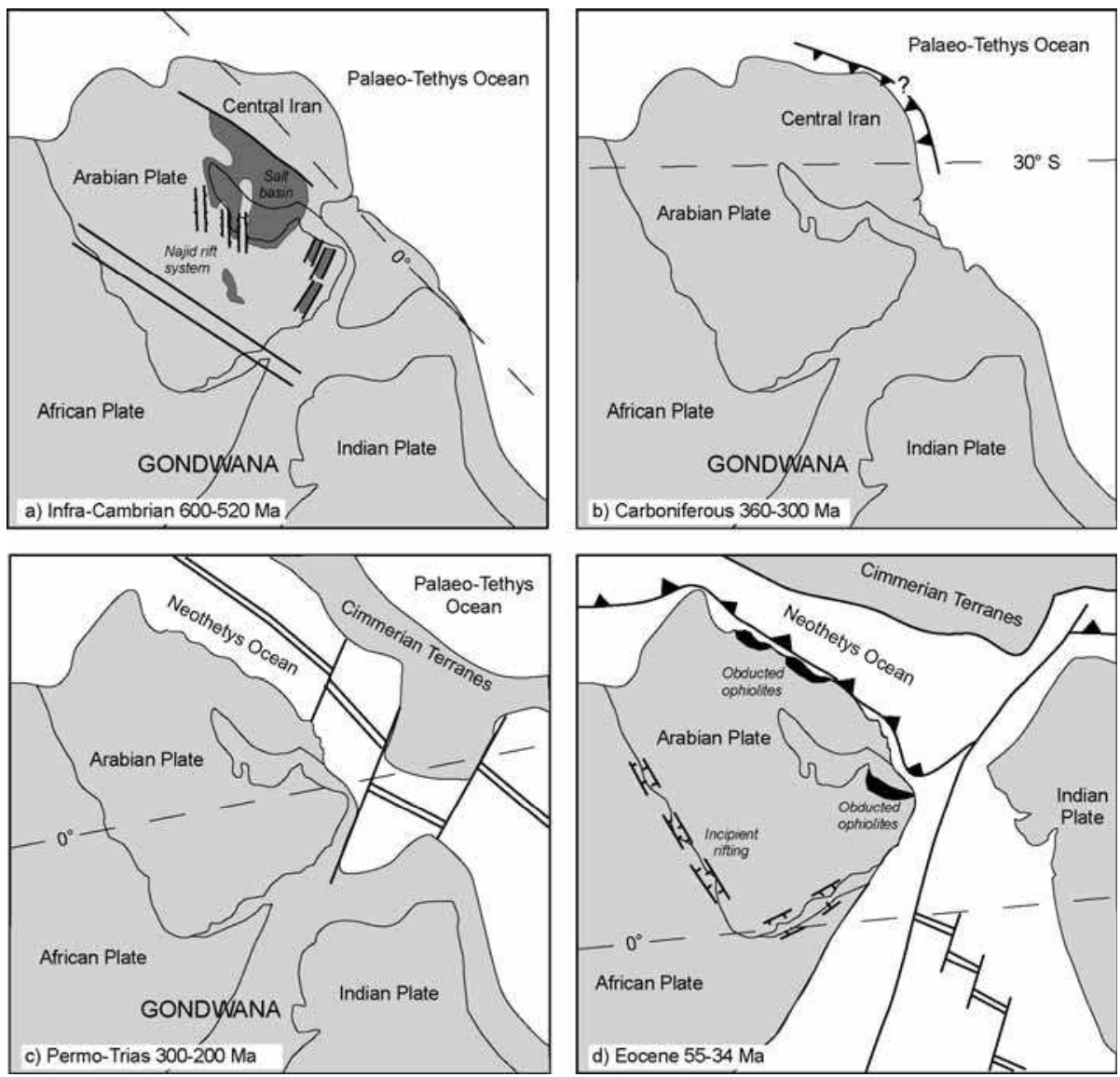

Fig. 4. Simplified plate tectonic evolution of the Persian Gulf and Arabian Peninsula, modified from Loosveld et al. (1996), Sharland et al. (2001), Stampfli and Borel (2004)

It is widely accepted that the tectonic history of the Arabian Platform has been influenced by the inheritance of the Precambrian structural highs forming an unstable basement for the basin. According to most authors, these deep structures have been repeatedly reactivated during the Phanerozoic, triggering the uplift of salt diapirs (Edgell, 1996) and basementcored structures (Wender et al., 1998), and controlling the geometry and deposition of the overlying sedimentary cover (Edgell, 1992; Konert, 2001; Pollastro, 2003). The deformation structures in the Gulf area are essentially caused by the movements of the Hormuz evaporites of late Proterozoic to earliest Cambrian age (often referred to informally as 'Infracambrian') at the base of the sedimentary succession (Al-Husseini, 2008), which have created salt domes, anticlines and diapirs characterized by continuous growth since at least the Jurassic (Edgell, 1996; Sugden, 1962). A steady diapiric rise during the Early Palaeozoic has also been described, as well as several main phases of salt movement in the PermoTriassic, middle Cretaceous, Eocene-Oligocene and Neogene (Carruba et al., 2007). The time-correspondence between the phases of diapiric uplift and the regional tectonic events 
suggests that the latter could have triggered salt movements. The Arabian coastal sector and its interior are mainly affected by very large (hundreds of kilometres long by tens of kilometres wide), roughly north-south trending anticlines, with gently dipping flanks and sometimes a subtle topographic expression. These structures are of paramount economic importance, forming the oil and gas traps of the most prolific hydrocarbon basin in the world. Most of these anticlines are interpreted (e.g. Ghawar and Khurais) as formed by draping of the sedimentary cover over systems of major north-south basement blocks (originated during the Najd rifting episodes) delimited by faults (Edgell, 1992). Horst uplift associated with strong crestal erosion in the Carboniferous is particularly well documented in the Ghawar structure (Wender et al., 1998). The folding of the overlying succession in Ghawar has been attributed to horst reactivations in response to Zagros rifting (Early Triassic), the First Alpine Orogeny (Late Cretaceous) and the Second Alpine Orogeny (MidLate Tertiary). Some elongated anticlines, generally smaller, in the Arabian Platform and Persian Gulf, have cores of deep-seated salt (Edgell, 1992). The basement at the core of structures is revealed by geophysical (gravity and magnetic) investigations (Edgell, 1992; Johnson and Stewart, 1995), and local subsurface data (Wender et al., 1998), while seismic evidence has been gained so far only in some cases in the internal parts of the platform in Arabia (Edgell, 1992; Sharland et al., 2001).

\section{The Qatar-South Fars Arch}

The Qatar-South Fars Arch is a very large (over $100 \mathrm{~km}$ wide and $300 \mathrm{~km}$ long) and longlasting (several hundreds of Ma) warping of the Phanerozoic sedimentary succession of the Arabian Platform in the Persian Gulf. Its onshore expression is the Qatar peninsula, which is marked by a low-relief topographic feature that protrudes some $150 \mathrm{~km}$ into the Persian Gulf. The peninsula consists of outcropping Eocene and Mio-Pliocene units (Alsharhan and Nairn, 1994; Dill et al., 2003; Nasir et al., 2008), very gently deformed in a north-south regional anticline (figure 5). The Qatar regional anticline continues offshore in a northnortheast to northeast direction where the arching of Arabian Platform sedimentary cover underneath the Quaternary sediments of the Persian Gulf is known from geophysical data. Talbot and Alavi (1996) considered the continuation of the Qatar-South Fars Arch farther north into the Zagros belt, where a north-south trending zone, up to $100 \mathrm{~km}$ wide, is aligned with the north-south lineaments of the Arabian Platform that have been repeatedly reactivated. This zone constitutes the persistently high area (as revealed by stratigraphically thinned units) of the Fars Platform, and is characterized by the absence of salt diapirs, which occur estensively to the west and east of it.

The Qatar-South Fars Arch has been described as a comparatively reduced Phanerozoic sedimentary cover draping a repeatedly rejuvenated Precambrian basement horst block. Indications of that include:

1. the distribution of salt diapirs of Late Proterozoic Hormuz formations in the area, which are present only southeast and northwest of the Arch, and could delineate a north-northeast to northeast basement feature aligned with the other basement structures of the "Arabian trend" that affect the Arabian coastal sector and its interior (Al-Husseini, 2000; Edgell, 1992);

2. the relative thinning of the Mesozoic sedimentary section over the Qatar-South Fars Arch (Alsharan and Nairn, 1997); 
The Qatar-South Fars Arch Development (Arabian Platform, Persian Gulf):

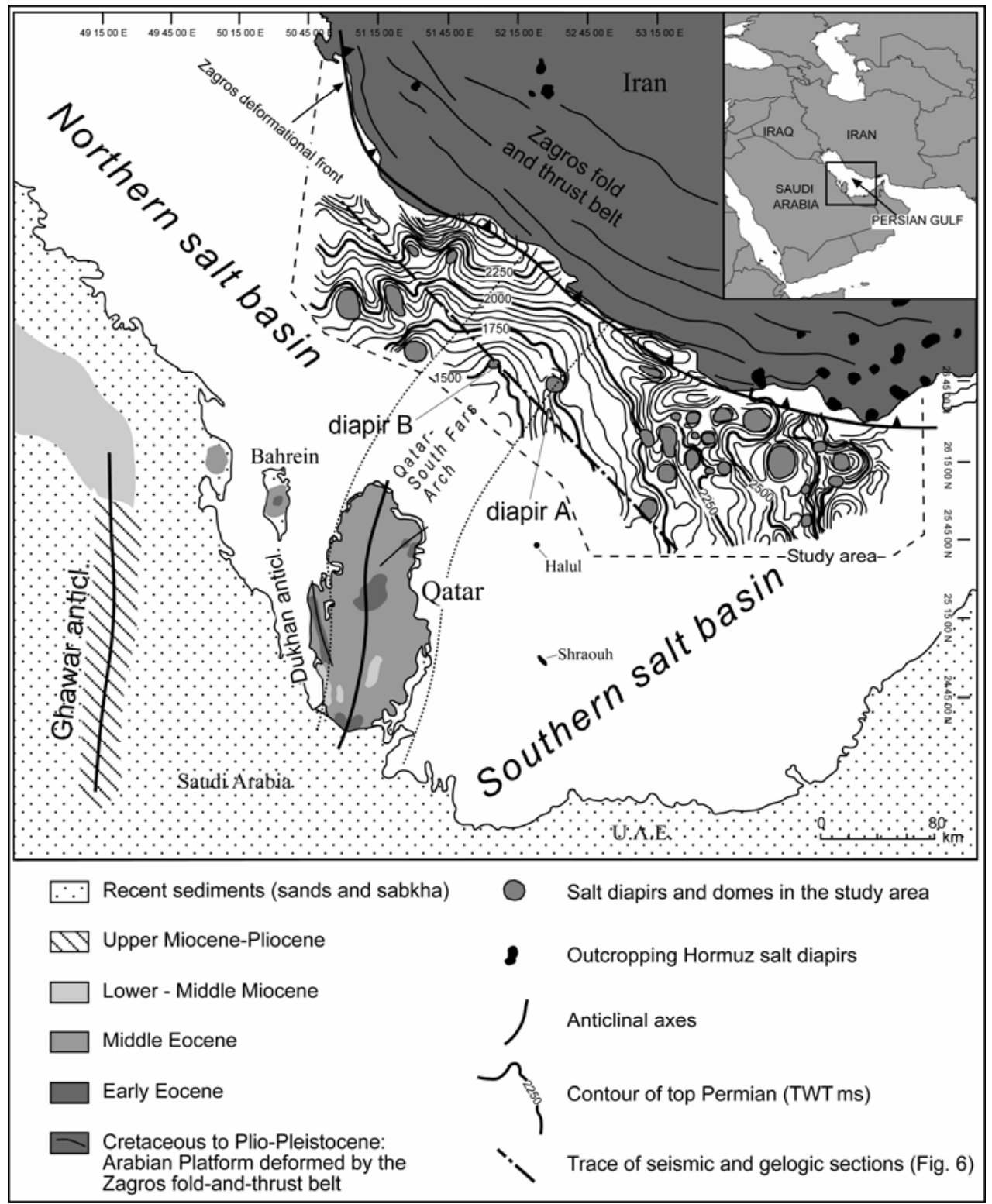

Fig. 5. Tectonic map of the central Persian Gulf showing the seismic contour map in time (twt ms) of near top Permian in the study area

3. the growth of the Qatar-South Fars Arch during several periods of time: Alsharan and Nairn (1994) report emergence at the end of the Triassic to Early Jurassic, and during the Turonian; minor uplifts in the Early-Middle Eocene and at the end of the Middle Eocene. Then, during the Late Eocene to Oligocene a main phase of Qatar-South Fars 
Arch uplift occurred (concurrently with the development of a major unconformity). Another uplift phase started in the Early Miocene and increased in intensity during Late Miocene-Pliocene;

4. the Qatar peninsula anticlinorium with outcropping Tertiary units, strongly contrasting with the surrounding Quaternary cover (figure 5).

So far, there is no published subsurface evidence (well or seismic data) of the basement high below the Qatar-South Fars Arch and adjacent areas in the Persian Gulf. As far as its depth is concerned, the top of basement high below the Qatar peninsula, as shown by the tentative basement map drawn by Konert et al. (2001), is placed at a depth of $4-5 \mathrm{~km}$. Depth to basement rapidly increases to $8-9 \mathrm{~km}$ in the Persian Gulf west, north and east of Qatar. The thickness of the sedimentary cover in the Persian Gulf has been generally quoted by other authors as being more than $10 \mathrm{~km}$ (Alsharhan and Nairn, 1994), $12 \mathrm{~km}$ (Pollastro, 2003) or 13 km (Edgell, 1992, 1996).

\section{Seismic interpretation}

A 2D seismic coverage with a $2 \times 2 \mathrm{~km}$ grid has been interpreted in the Iranian sector of the Central Persian Gulf (figure 5). Acquisition was performed in 1999 with a $4600 \mathrm{~m}$ streamer and $7 \mathrm{~s}$ of record length; processing consisted of a routine including deconvolution, radon multiple removal, common offset DMO (Dip Move Out), stack and migration.

Following well-to-seismic calibration we interpreted and correlated 17 key horizons on a 340 $\mathrm{km}$ long composite seismic profile stretching in a northwest-southeast direction perpendicular to the Qatar-South Fars Arch (figure 5). Well calibration was available down to the top of the Permian (1500-2200 ms TWT); from this level downwards the seismic quality and continuity of reflections tend to rapidly degrade. Seismic evidence of basement is lacking below the culmination of the arch. On the flanks of the Qatar-South Fars Arch, the Hormuz salt is buried at a depth greater than $7 \mathrm{~s}$ TWT, beyond the lower limit of seismic data, as indicated by concave reflections bordering relatively seismic-transparent zones at these levels (figure 6).

The time interpretation was converted to depth using interval velocities measured from wells. A constant velocity of $4000 \mathrm{~m} / \mathrm{s}$ has been used for the interval from top-Permian to the base of the section, giving a profile as deep as $14 \mathrm{~km}$ (figure 7). The depth conversion did not significantly alter the geometric features visible in the time section. The section across the Qatar-South Fars Arch (figure 7) is characterized by an overall convex-upward arrangement of reflectors, featuring a $250-300 \mathrm{~km}$ wide regional warping with extremely low-dipping limbs $\left(0.4-0.7^{\circ}\right.$ at top-Permian) and an overall increase in structural dip downwards. Several thinning phenomena highlighted by the interpretation of the MesoCenozoic horizons are visible on both limbs of the arch in several intervals. The line drawing below the top of the Permian shows seismic reflections with progressively increasing dips in the whole pre-Permian succession (figure 8). No discontinuities in seismic features and reflector geometries are visible in the deepest parts of the Arch culmination, where the reflections appear to be warped conformably with the overlying units. The sequence above the Oligocene unconformity does not appear to be folded, but tilted to the northwest with a series of onlap phenomena occurring in different phases. The main erosional unconformities (Turonian, Oligocene) are underlain by truncations whose geometries testify to structural growth before the erosional period (figure 9). 
The Qatar-South Fars Arch Development (Arabian Platform, Persian Gulf):

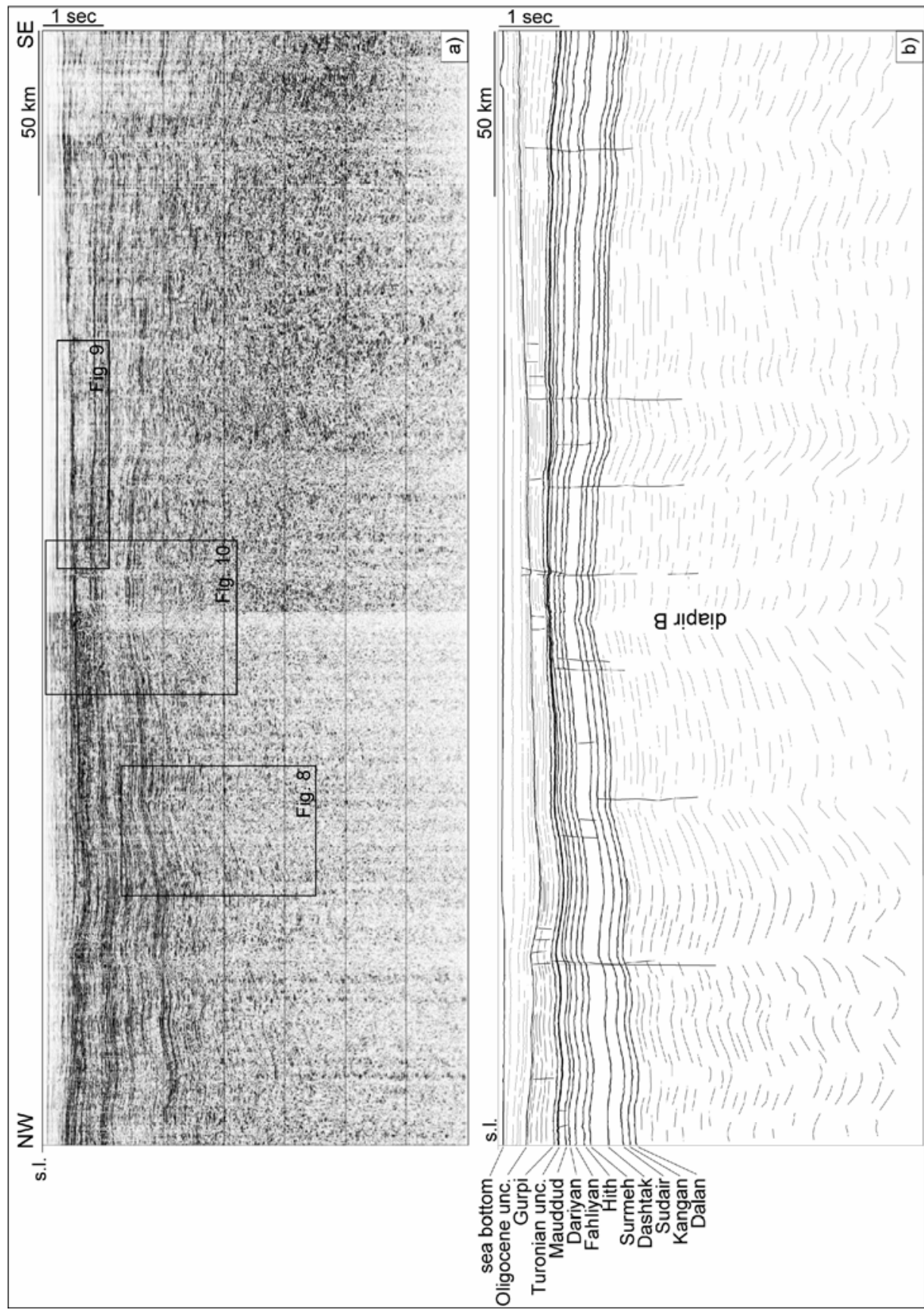

Fig. 6. Migrated seismic section across the Qatar-South Fars Arch (a) and interpreted linedrawing (b) (for location see Fig. 5) 


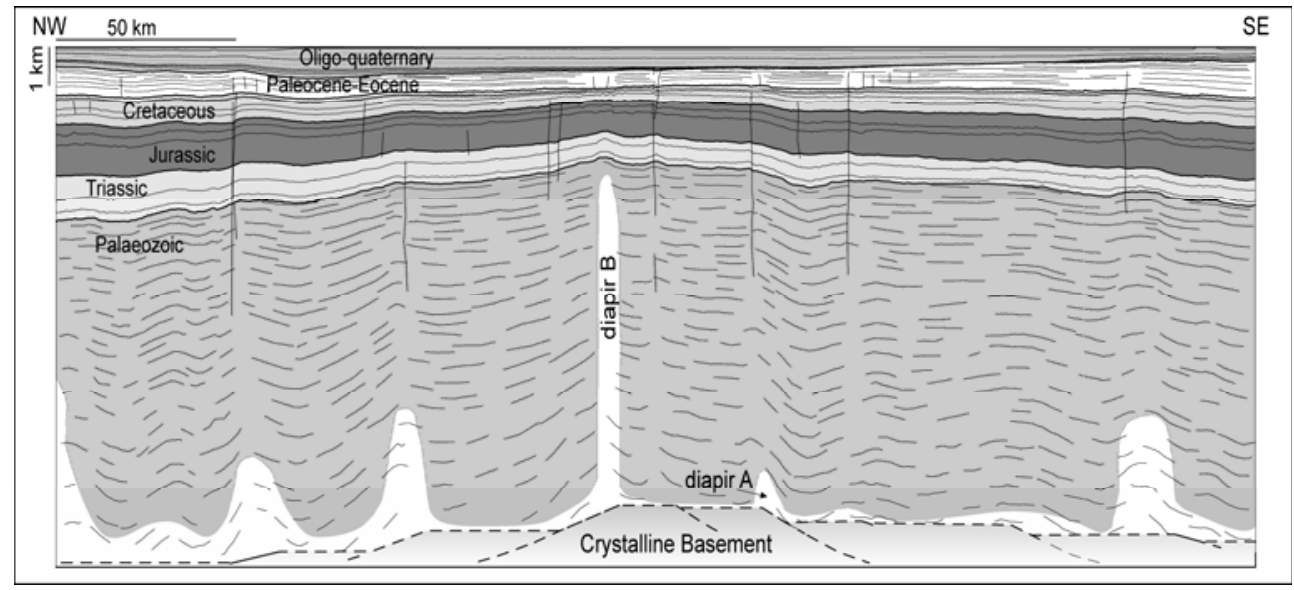

Fig. 7. Geologic section across the Qatar-South Fars Arch derived from depth conversion of the seismic line of Fig. 6 (for location see Fig. 5). Interpreted salt diapirs in white

Relatively abrupt changes in reflection dips (flexures) are visible along subvertical lineaments, particularly at the sides of the central 100-km-wide zone that can be considered the culmination of the Arch. These lineaments correspond to very small displacement faults in the Mesozoic section; there is no appreciable displacement of reflections in the deeper part. A seismic transparent zone, about $4 \mathrm{~km}$ in width, crosses the section from its base up to the Oligocene unconformity few kilometres west of the crest of the arch, and it is surrounded by concave-upwards reflections (figure 10). At its top, seismic reflections of the Oligocene unconformity and the underlying section appear to be arranged in a collapse-like structure 250-300 ms TWT thick. Other similar features are present on the crest of the Arch in our study area, but they appear as transparent zones beneath collapse structures below the Turonian and Oligocene unconformities with limited thickness (100-200 ms) and with an absence of lateral concave-upwards reflections.

The interpretation and correlation of the seismic horizons over the area covered by the seismic grid led to the construction of a time structural map of the top-Permian (figure 5). Because of the general parallelism of the overlying horizons (except the Oligocene unconformity and Neogene reflectors), the maps of the Mesozoic and Lower Tertiary reflectors will tend to mimic that of the top Permian (with reduced dips). The map of figure 5 highlights the distribution of salt structures indicated by the circular to elliptical, 5 to 20 $\mathrm{km}$ wide, folds of the structural surface on both sides of the Qatar-South Fars Arch. In particular, the map shows that the extent of the regional warping reaches a wavelength as great as $200 \mathrm{~km}$ and covers a large part of the area with diapirs: the folded area of the QatarSouth Fars Arch actually encompasses areas with original salt (sub)basins or their borders. In figure 11 a seismic section across a diapir in the Northern Gulf Salt Basin shows the typical features of these kinds of structures: diapirs with an average diameter of $10 \mathrm{~km} \mathrm{(5-15}$ $\mathrm{km})$ piercing the stratigraphic sequence at different levels. The salt bodies appear to have vertical or sometimes slightly overhanging flanks, although the actual shape of steep diapirs flanks is not properly imaged by the conventional seismic acquisition and processing. The folded overburden is characterized by rim synclines surrounding the salt diapirs and downward increasing of the dip of the layers. 
The Qatar-South Fars Arch Development (Arabian Platform, Persian Gulf): Insights From Seismic Interpretation and Analogue Modelling

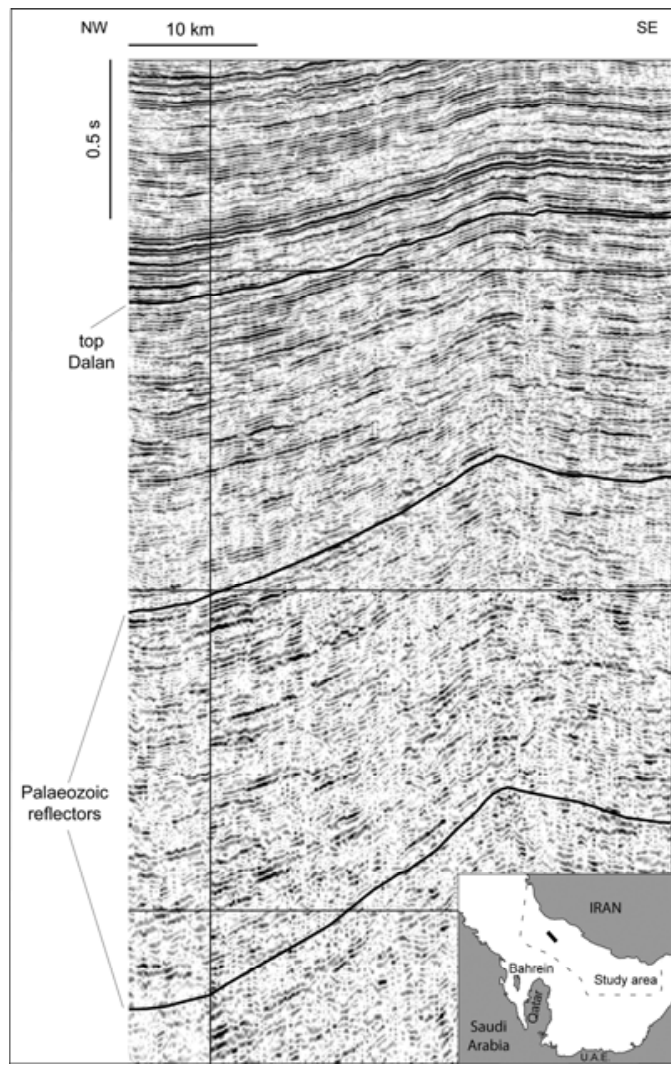

Fig. 8. Detailed view of part of the seismic section of figure 6 showing the progressive increase of the dip of the reflectors with depth caused by a continuous growth of the QatarSouth Fars structure. Inset map: location of the seismic section

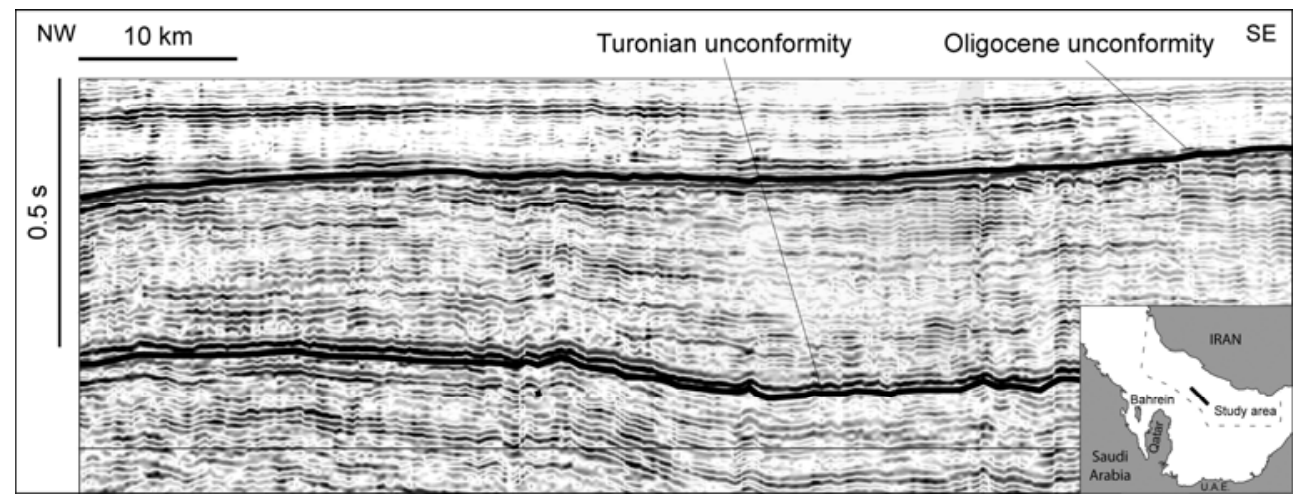

Fig. 9. Detailed view of part of the seismic section of figure 6 showing the Turonian and Oligocene unconformities. Inset map: location of the seismic section 


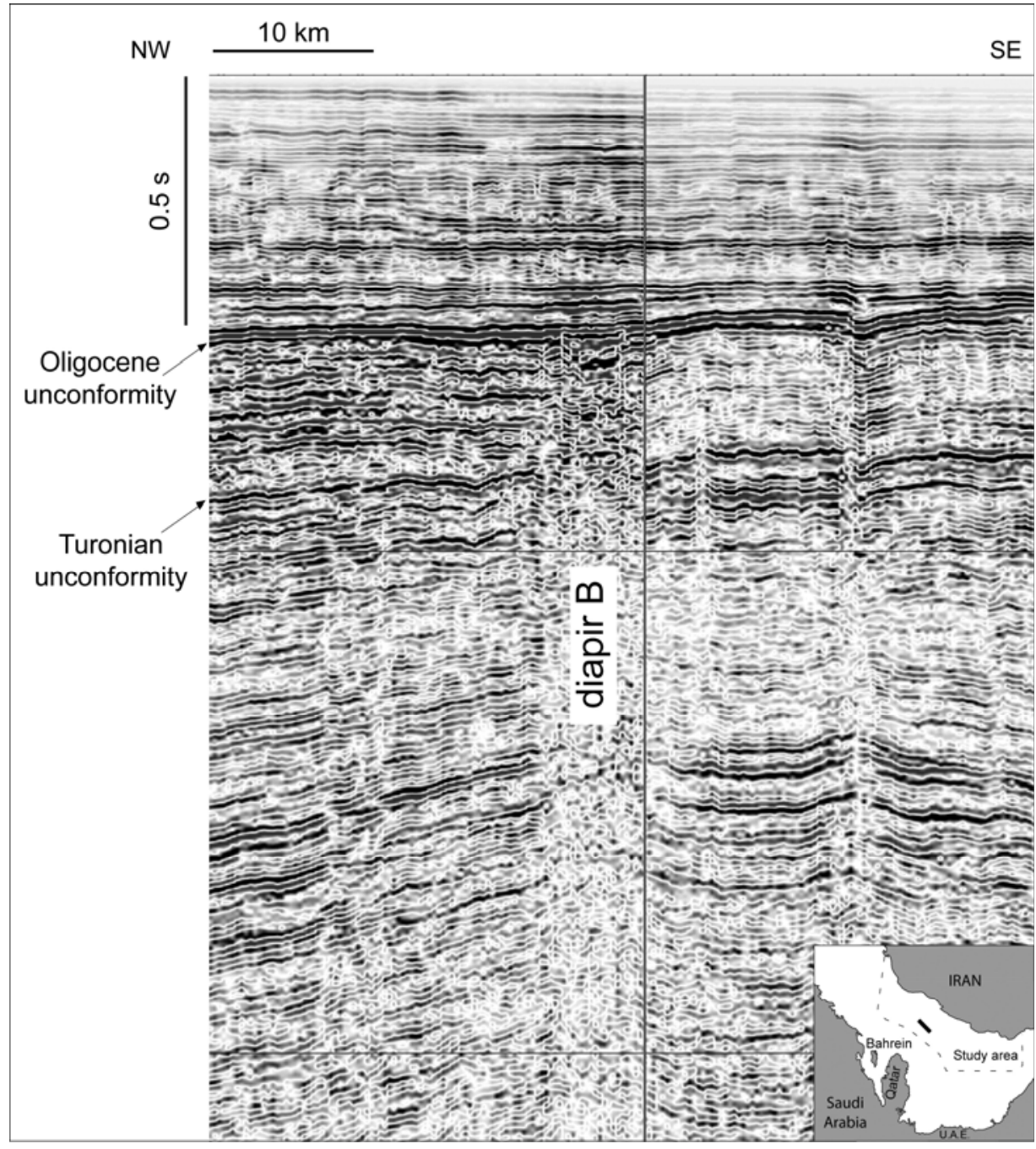

Fig. 10. Detailed view of part of the seismic section of figure 6 showing the diapir B. On the right (SE) of the section a minor fault zone cutting the Cretaceous-Lower Tertiary succession is visible. Inset map: location of the seismic section

The progressive flattening (restoration to a horizontal datum) of the horizons in the regional geological section of figure 7 shows the development of the Qatar-South Fars Arch with time. This process has been carried out under the assumption that the flattened horizons were the tops of originally flat rock units, which we consider a fairly good approximation in a 2D regional section within a basically undeformed intracratonic, passive margin setting. Compaction and erosional effects have not been considered due to lack of data; however, we think that flattening of the main unconformities has not introduced significant geometric errors at this scale because of their regional nature. In 
The Qatar-South Fars Arch Development (Arabian Platform, Persian Gulf):

any case, flattening at unconformities aimed to show the relative geometric relationships between the under- and overlying strata in order to illustrate tectonic movements of the underlying section, regardless of the initial sub-horizontal or uniformly tilted geometry of the unconformity surface.

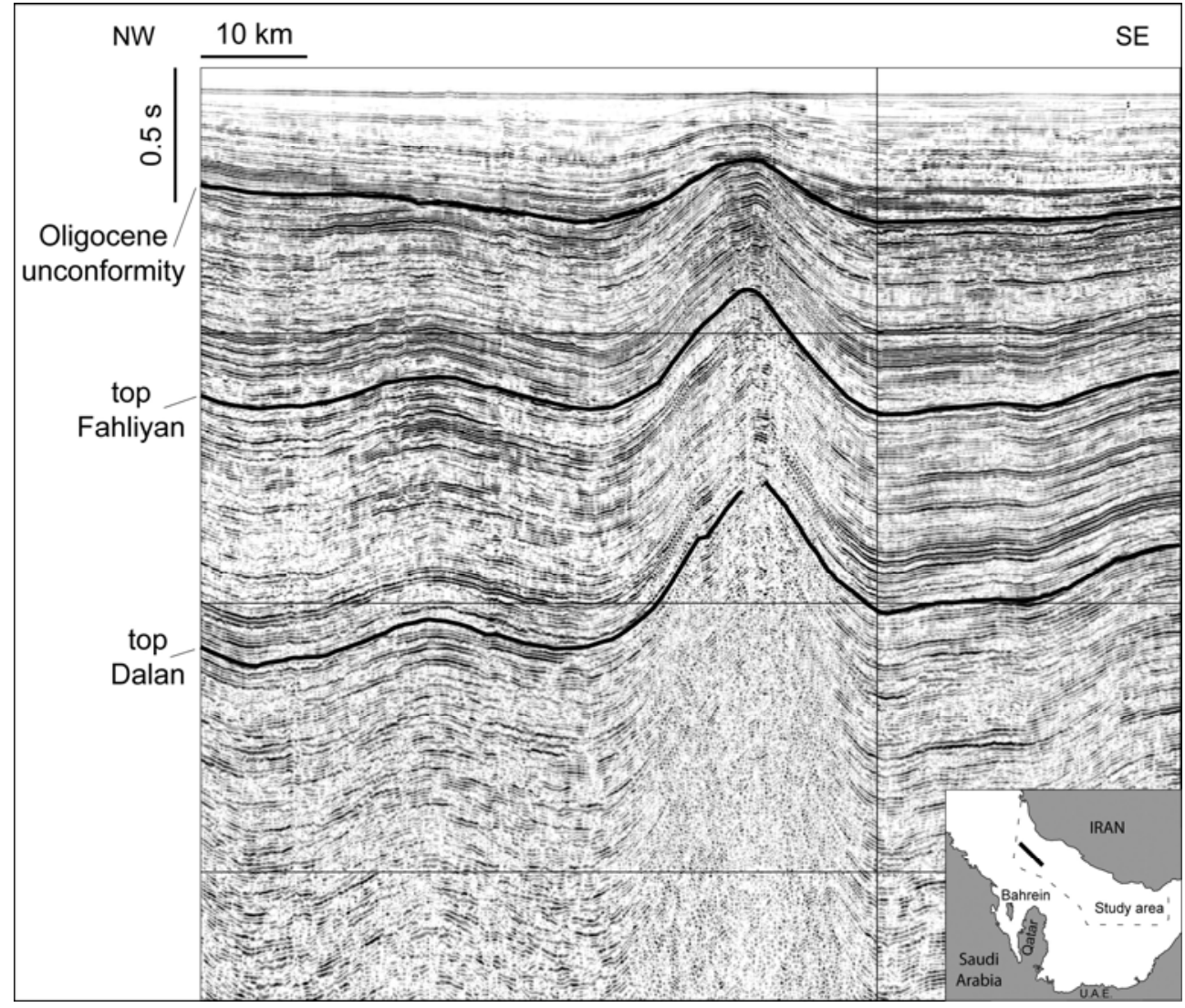

Fig. 11. Seismic section running across a diapir in Northern Gulf Salt Basin. Inset map: location of the seismic section

\section{Geological interpretation}

The regional geological section of figure 7 shows all of the main structural features occurring in the central Persian Gulf: the Qatar-South Fars Arch, salt domes and diapirs (although salt cores are not directly crossed by the section), flexuring and minor faulting of the sedimentary cover. The first-order structure is the Qatar-South Fars Arch regional anticline, several tens of kilometres wide. The Arch is a very gentle, broad warping of the sedimentary cover, an order of magnitude larger than the diapiric structures. The contrast between the wavelengths of the Arch and the salt diapirs and pillow deformations is remarkable. The whole, very thick sedimentary sequence (at least $14 \mathrm{~km}$ ) is draped across 
the basement block to form the arch without apparent major faulting. The deformation related to the Qatar-South Fars Arch involves large parts of the Southern and Northern Gulf Salt basins. According to the currently accepted models of the Arabian Plate basement structure, the crystalline basement is assumed to be split by faults into several blocks with different structural elevations. A basement high is thus inferred in the core of the QatarSouth Fars Arch. This basement high is not visible on the seismic sections and could be located at a depth of at least 13-14 km (figure 7). In plan view, following the traditional approach, we can set the limits of the basement high beneath the Qatar-South Fars Arch by mapping the areas without salt-related phenomena. The salt structures closest to the crest of the Arch are the Dukhan anticline (elongated structure assumed to be a deep-seated salt anticline: Qatar General Petroleum Corporation and Amoco Qatar Petroleum Company 1991) to the west, and the circular diapir A to the east (figure 5). The diapir A is located in an area of rapidly changing reflector dips, suggesting the presence of a deepseated sharp discontinuity at its base (figure 7). A basement fault would also account for the geometry of the Dukhan anticline (Edgell, 1996). The circular feature on the crest of the arch (figure 5) and corresponding to the seismic transparent zone bordered by concave reflectors visible in the regional section (figures 6, 7 and 10) may be interpreted as a small diapir (diapir B) with salt dissolution phenomena at its top (collapse-like structures).

The general progressive increase in structural relief of the Qatar-South Fars Arch with depth indicates that this structure acted as a long-lasting area of positive relief in the Phanerozoic, with continuous phases of uplift interspersed with short periods of more uniform subsidence. Seismic data reveal its continuous activity during the Palaeozoic, and well log correlations confirm its persistence as a structural high at least from the Jurassic until the mid-Cretaceous, with a reduction of the Cretaceous to Middle Jurassic succession at the top of the Arch of about 30\% (Edison unpublished data).

At the present time the salt structures appear to be different on the two sides of the QatarSouth Fars Arch: they are more numerous and generally smaller (5-10 km to $20 \mathrm{~km}$ in few cases) in the Southern Gulf Salt Basin and fewer and larger $(15-20 \mathrm{~km})$ in the Northern Gulf Salt Basin. Moreover, in the Southern Basin most of them have a circular shape in plan view, while in the Northern Basin they mostly have an elliptical shape and are connected by elongated ridges interpreted as possible deep-seated salt walls (figures 5, 6). In some cases, there is no seismic evidence of salt below these domes, but their circular shape in plan view and growth history (inferred from the continuous downward increasing dips of the limbs) support the conclusion of a component of salt diapirism in the creation of these structures. In other cases, salt appears to pierce most of the sedimentary succession and push up the most recent sediments into positive bulges of the seabed. The dips of the limbs of the salt domes are about $3-4^{\circ}$ (at top-Permian), but this could represent a minimum, approximate value because the processing of seismic data was not addressed with regard to imaging of the diapir limbs. An attempt of a quantitative or semiquantitative evaluation of the amount of salt in the diapirs is hampered by their incomplete imaging, both in their lateral and bottom limits. No data on the amount of salt dissolution is available.

The abrupt changes in reflection dips along subvertical lineaments in the deeper part of the section are mostly lined up with overlying, small displacement faults in the Mesozoic 
section. This minor faulting can be interpreted as the effect of basement faults on the sedimentary cover, in the presence of an interlayered ductile level that tends to mechanically decouple the deformations (e.g. Higgins and Harris, 1997; Koyi and Petersen, 1993; Maurin, 1995; Nalpas and Brun, 1993; Vendeville et al., 1995; Withjack et al. 1989, 1990), the degree of decoupling being related to the thickness of the ductile layer (Withjack and Callaway, 2000). The most accentuated flexures/faults are localized in correspondence of diapir A (figures 5,7) and symmetrically to the west of the crest of the Arch, suggesting deep-seated major faulting along these trends and therefore the location of the main high separating the northern and southern Infracambrian salt basins. Notwithstanding the presence of a number of these faults, it can be seen that the overall warping of the sedimentary sequence to form the Qatar-South Fars Arch has been accommodated by folding or draping without apparent major faulting.

In figure 12 the interpreted regional geological section is represented together with five flattenings related to the subsequent stratigraphic levels: Oligocene unconformity (circa 28$30 \mathrm{Ma}$ ), Turonian unconformity (circa $90 \mathrm{Ma}$ ), top Hith (Tithonian, circa145 Ma), top Dashtak (Norian, circa $210 \mathrm{Ma}$ ) and Dalan (Permian, circa $250 \mathrm{Ma}$ ). The analysis of each stage of the retro-deformation allows us to reconstruct the history of the Qatar-South Fars Arch during the following time intervals.

1. Palaeozoic (figure 12f): a continuous and symmetric growth of the structure can be inferred by the progressive increase of the dip of the reflectors with depth (figure 8), particularly noticeable toward the lower part of the section (Early? Palaeozoic).

2. Early Triassic-Norian (figure 12e): a considerable thickening of the sedimentary succession is visible, especially in the northwestern sector of the arch, indicating an asymmetric development of the anticline. This phenomenon can be explained by the reactivation during this period of the north-south trending structures located near the Qatar Peninsula, such as the Ghawar fault system (Wender et al. 1998), and possibly by a subsequent stronger halokinetic activity in the Northern Gulf Salt Basin.

3. Norian-Jurassic (figure 12d): a thickening of the sedimentary succession in the northwestern part of the arch is detectable, probably for the same reasons as already indicated for the early Triassic.

4. Early Cretaceous-Turonian (figure 12c): a significant growth of the Qatar-South Fars Arch is indicated by the thickening of the sedimentary succession symmetrically along the two limbs of the structure. The movements were practically continuous and uninterrupted, with only modest changes of velocity.

5. Turonian-Oligocene (figure 12b): during the Late Cretaceous and Paleogene the deformation activity decreases, as indicated by a minor thickening of the succession along the two limbs of the arch. The Coniacian probably represents an interval of stasis. At the top of this interval, several erosional truncations of the reflectors are visible (figure 9). A pre-Oligocene period of growth is shown by discordant convex reflectors truncated by the Oligocene unconformity.

6. Oligocene-Present (figures 7, 12a): the Qatar-South Fars Arch is not growing in the study area. The Zagros foredeep development is the only main deformational event, registered in the section by the thickening of the succession in the northwestern sector of the Arch, where the Zagros external deformational front is closer. 


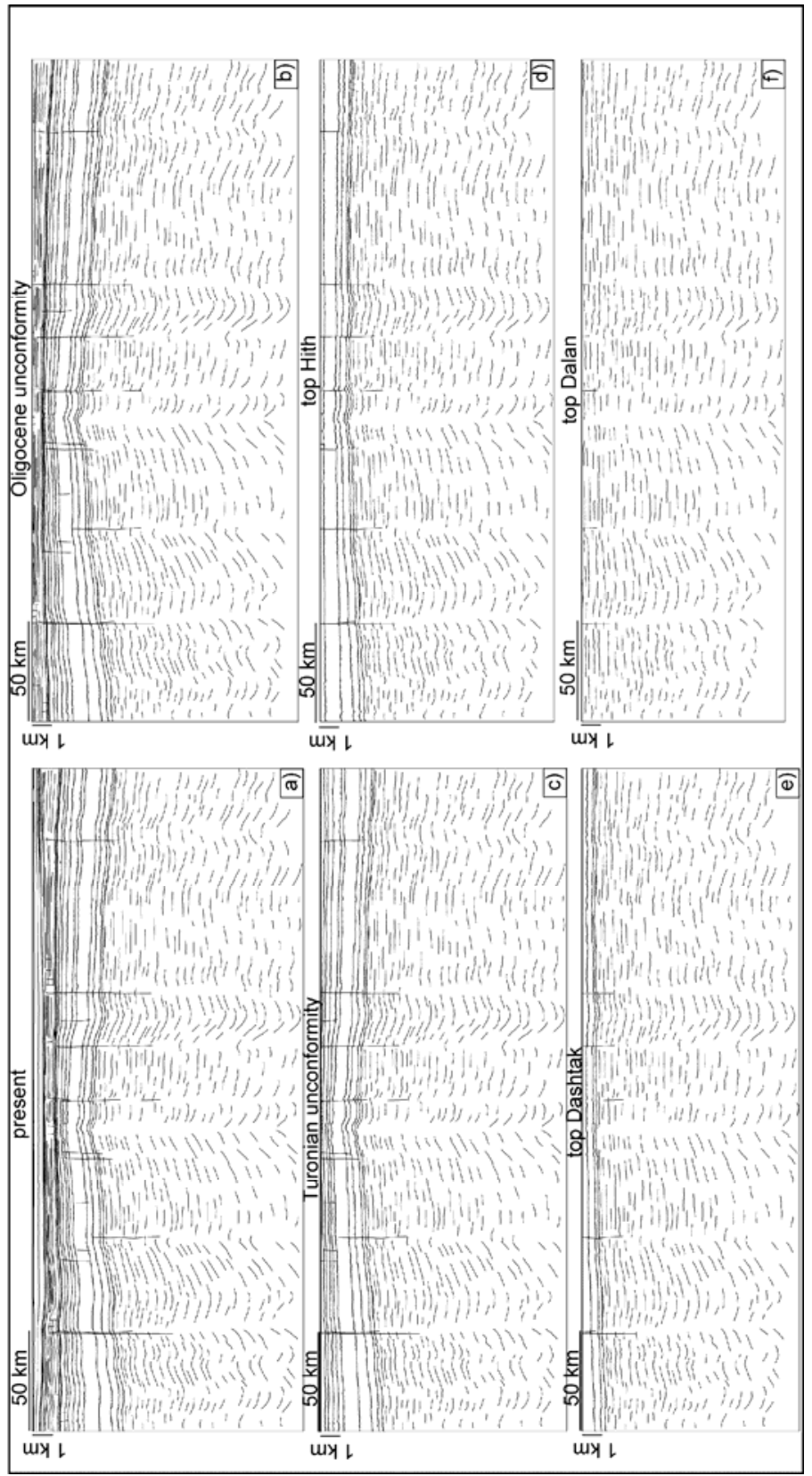

Fig. 12. Undeformed regional geologic section (a) across the Qatar-South Fars Arch (see figure 7). The same section flattened on the Oligocene unconformity (b), Turonian unconformity (c), top Hith (Tithonian) (d), top Dashtak (e) (top Norian) and top Dalan (f) (near top Permian), illustrating the progressive development of the structure 


\subsection{Possible mechanisms of development}

As far as the origin and dynamics of this type of intracratonic deformation is concerned, compressive intraplate deformations due to far-field stresses acting at the plate boundaries and warping sectors of the plate interior (e.g. Nikishin et al. ,1993) or, alternatively, eastwest (trans)tensional stresses reactivating the supposed basement high coring the QatarSouth Fars Arch, do not adequately explain the continuing activity of the arch over several hundreds of millions of years. These two mechanisms contrast with the accepted geodynamic reconstructions, which consider major episodes of divergence and convergence in a northeast-southwest direction, along the northwest-southeast margin of the Arabian Plate; these tectonic trends are almost perpendicular to the Qatar-South Fars Arch anticline (Sharland et al., 2001), which has a north-south to northeast-southwest axis. Moreover, the dimensions of the arch are about one order of magnitude greater that the other north-south trending "Arabian Structures" and, in the seismic interpretation, no major faults cutting the arch have been detected. The existence of widespread and long-lasting salt tectonics in the Persian Gulf suggests an alternative mechanism to basement block reactivation that can account for the peculiar structural features of the Qatar-South Fars Arch and its evolution and persistence through time. The following elements are at the heart of our model:

1. salt-related structures over the Qatar-South Fars Arch are basically absent or very limited in number compared with adjacent areas (Northern and Southern Gulf Salt basins): substantially, the small-diameter diapir B (the less than $4 \mathrm{~km}$ wide) is the only diapir interpreted on the top of the arch. This implies the presence of a general reduced thickness of the mobile Hormuz salt layer over a fault-controlled basement high, possibly intersected by small salt basins (the presence of a large belt of non-evaporitic facies is also possible). In fact, a strong positive relationship between salt thickness and diapir wavelength was found, for example, in the North Sea by Hughes and Davison (1993);

2. The abundance of diapirs in the Southern and Northern Gulf Salt basins. This means that widespread salt diapirism or rise (and possibly subsequent dissolution) could have removed an unquantified but large amount of the Hormuz evaporites from the base of the sedimentary succession;

3. There are good time correlations between the deformation of the arch and the diapiric phenomena. Specifically, Carruba et al. (2007) indicated the continuous rise during the Palaeozoic of a salt structure immediately to the north of the Qatar-South Fars anticline that is in good agreement with the continuous flexure observed during the same period in the regional section after the flattening of the top-Permian (figure 12f);

4. Approximately, the height difference between the Qatar-South Fars Arch and the adjoining regions (corresponding in our interpretation to the height difference between the crest and trough of the Qatar-South Fars mega- anticline) appears compatible with the salt Hormuz Formation thickness (probably more than $2500 \mathrm{~m}$ ).

These conditions lead us to think that the basal salt withdrawal on a regional scale in the Infracambrian sub-basins could have contributed to the regional warping of the overburden over the main basement block system of the Qatar-South Fars Arch.

\section{Analogue modelling}

In order to verify if the Qatar-South Fars mega-anticline could have been caused by the Hormuz salt withdrawal at the sides of a basement structural high where the salt is lacking 
or very thin, a set of analogue experiments have been carried out in the laboratory, using a silicone putty layer in order to simulate the salt behaviour of the Hormuz Formation, and loose quartz sand to simulate the overlying competent sedimentary succession,. In our models we have tried to reproduce the regional geological section depicted in figure 7 , which crosses the Qatar-South Fars Arch and has been reconstructed by seismic interpretation. The models do not aim to simulate the actual three-dimensional distribution of salt and basement structures, which is unknown in details, but are built to be appropriately scaled in two dimensions to give insights on the possibility of the mechanism proposed.

Models with silicone and sand have been developed by several groups to simulate the processes of gravity-induced deformation of a sedimentary pile above salt, with or without synchronous sedimentation (Brun and Fort, 2004; Brun and Mauduit, 2008; Cobbold et al., 1989; Cobbold and Szatmari, 1991; Fort et al., 2004a, 2004b; Ge et al., 1997; Gaullier et al., 1993; Mauduit and Brun, 1998; Mauduit et al., 1997a, 1997b; McClay et al., 1998; Vendeville et al., 1987; Vendeville and Jackson, 1992a, 1992b). Most of these analogue experiments simulating gravity-driven deformation use models in which brittle sediments are represented by sand, and salt deposits by silicone putty. These experiments have been extremely useful in understanding salt tectonics and associated structures as diapirs and folds. Detailed descriptions of the equipment, rheology of materials and analysis of models have already been presented in a number of previous studies (Faugère and Brun, 1984; Gaullier et al., 1993; Vendeville and Cobbold, 1987), which discuss scaling with regard to nature.

\subsection{Materials and scaling}

Our physical models use dry quartz sand to simulate brittle sedimentary rocks. The sand shows near-perfect Navier-Coulomb behaviour, with a grain size of 100-300 $\mu \mathrm{m}$. It has negligible cohesion, an internal friction angle of about $34^{\circ}(\Phi \mathrm{i}=0.67)$ and a bulk density of $1.3 \mathrm{~g} / \mathrm{cm}^{3}$. The dry oxides used to colour the sand did not significantly modify its rheological characteristics. Sand is the best analogue for most sedimentary rocks in the upper continental crust, which obey Mohr-Coulomb behaviour (Byerlee, 1978; Weijermars et al., 1993). Silicone putty has been commonly used as a Newtonian material with a strainrate-dependent viscosity for modelling the ductile flow of incompetent décollement rocks such as evaporites (e.g. Cotton and Koyi, 2000; Weijermars et al., 1993). The Newtonian silicone polymer used in our experiments is polydimethyl-siloxane (PDMS, Dow Corning, SGM36) with a density of $965 \mathrm{~kg} / \mathrm{m}^{3}$ and a viscosity of $5 \times 10^{4} \mathrm{~Pa}$. For detailed rheology of this material and suitability as model analogue, see Weijermars (1986) and Weijermars et al. (1993). For a small-scale model to be representative of a natural example (a prototype), a dynamic similarity in terms of distribution of stresses, rheologies and densities between the model and the prototype is required (Hubbert, 1937; Ramberg, 1981). However, in gravitydriven physical experiments, where no external forces or displacements are applied, the modelling of ductile salt flow below a brittle substratum, with a mechanism of passive diapirism or gravity spreading, scaling of geometry, densities and rheology is sufficient for achieving dynamic similarity between the models and natural prototypes (Weijermars et al., 1993). In our experiments the scale ratios between models and prototype are $L^{*}=2.9 \times 10^{-6}(1$ $\mathrm{cm}$ in models represents approximately $3.5 \mathrm{~km}$ in nature), $g^{*}=1$ (models and geological prototype both deformed in same gravity field), $\rho^{*}$ (density ratio of the brittle overburdens) 
$=0.5$ (considering about $2600 \mathrm{~kg} \mathrm{~m}^{-3}$ as the average density of the sedimentary succession), $\rho_{\mathrm{d}}^{*}$ (density ratio of the basal ductile layers) $=0.4$ (considering about $2200 \mathrm{~kg} \mathrm{~m}^{-3}$ as the average density of the salt). The difference between these last two ratios is considered acceptable as the density ratio is not the primary parameter affecting the rise of diapirs under normal gravity (Weijermars et al., 1993). Modelling the flow and extrusion of salt diapirs due to lithostatic pressure requires scaling the viscosity. Viscosity $(\mu)$ may be scaled according to the expression:

$$
\mu^{*}=\left(\rho^{*} \mathrm{~b} \times L^{*}\right) / \varepsilon^{*}
$$

where $\mu^{*}$ is the viscosity ratio and $\varepsilon^{*}$ is the strain-rate ratio between the model and prototype (respectively $\mu_{\mathrm{m}} / \mu_{\mathrm{p}}$ and $\varepsilon_{\mathrm{m}} / \varepsilon_{\mathrm{p}}$ ).

Considering a displacement rate of the Hormuz salt of at least $1 \mathrm{~mm} / \mathrm{yr}$ (Bruthans et al., 2006) and a thickness of $3000 \mathrm{~m}$, we can evaluate a strain rate of about $10^{-14} \mathrm{~s}^{-1}$. Analysing the experiments, we can calculate an approximate strain rate of the silicone of about $10^{-5} \mathrm{~s}^{-1}$. Considering that we used in the experiments silicone putty with a Newtonian viscosity of 5 $x 10^{4} \mathrm{~Pa} \mathrm{~s}$, the viscosity of the salt is in the range of the right order of magnitude $\left(\sim 3 \times 10^{19}\right.$ $\mathrm{Pa}$ s). In fact, the effective viscosity of the salt in nature ranges from $10^{17} \mathrm{~Pa} \mathrm{~s}$ for small grain size and high temperature, up to $10^{20} \mathrm{~Pa}$ s for large grain size and low temperature, and the viscosity is strongly dependent upon grain size and moderately dependent upon temperature (van Keken et al., 1993). The ratio of the time $\left(t^{*}=t_{m} / t_{p}\right)$ is not particularly meaningful because the diapiric rise of salt in the study area is a discontinuous process, with long periods of inactivity. In the experiments with sedimentation during the diapirism, the sedimentation rate is then adapted to the rate of diapiric rise. Table 1 shows the values of the main physical parameters for both the natural prototype and analogue materials, and the corresponding scaling factors, according to the approach of Weijermars et al. (1993).

\begin{tabular}{llll}
\hline Parameter & Model & Prototype & Scale factor \\
\hline Lenght $l(\mathrm{~m})$ & $1 \times 10^{-2}$ & $3.5 \times 10^{3}$ & $2.9 \times 10^{-6}$ \\
\hline Density overburden $\rho_{\mathrm{b}}\left(\mathrm{kg} \mathrm{m}^{-3}\right)$ & 1300 & $\sim 2600$ & 0.5 \\
\hline Density ductile layer $\rho_{\mathrm{d}}\left(\mathrm{kg} \mathrm{m}^{-3}\right)$ & 965 & 2200 & 0.4 \\
\hline Gravity $g\left(\mathrm{~m} \mathrm{~s}^{2}\right)$ & 9.81 & 9.81 & 1 \\
\hline Strain rate $\varepsilon\left(\mathrm{s}^{-1}\right)$ & $\sim 10^{-5}$ & $\sim 10^{-14}$ & $\sim 10^{9}$ \\
\hline Viscosity $\mu(\mathrm{Pa} \mathrm{s})$ & $5 \times 10^{4}$ & $\sim 3 \times 10^{19}$ & $\sim 10^{-15}$ \\
\hline
\end{tabular}

Table 1. Nature and model parameters 


\subsection{Experimental procedures}

The experimental apparatus used in the models was a glass-sided sand-box, $90 \mathrm{~cm}$ long, 15 $\mathrm{cm}$ wide and $8 \mathrm{~cm}$ high, with a rigid structural rise (figure 13) placed in the middle of the glass basal plate. Friction along the sidewalls was reduced by coating them with graphite powder. A set of three experiments, with the same initial geometry, stratigraphy and boundary development conditions, were performed to verify the repeatability of the obtained results.

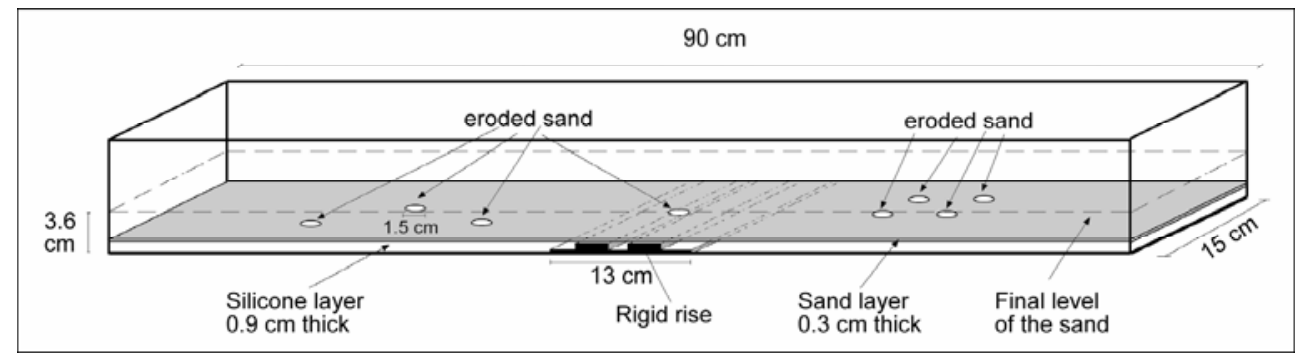

Fig. 13. Experimental apparatus and model settings used in the set of experiments to simulate the flow and withdrawal of a basal salt layer around a structural high, and the deformation of an overlying sedimentary succession

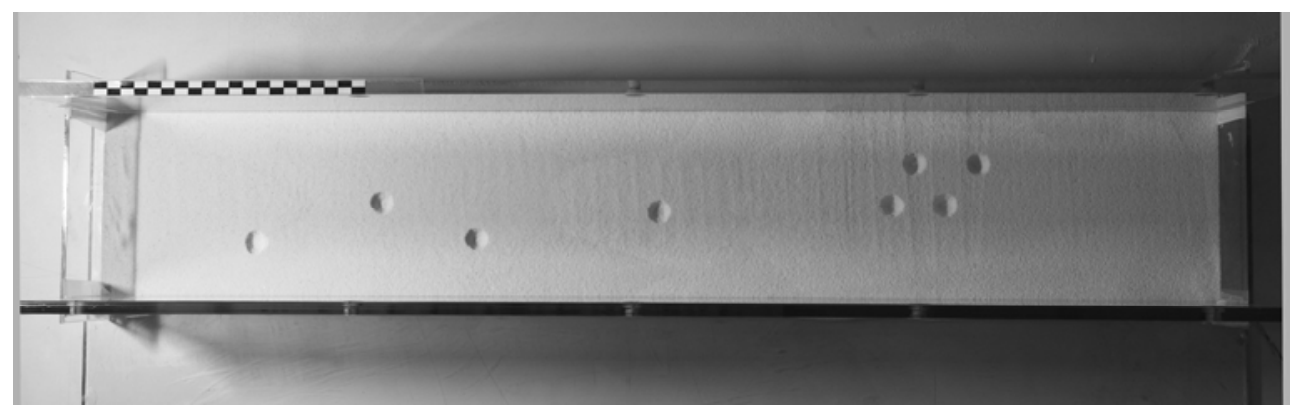

Fig. 14. Top view of the initial stage of one of the experiments of the second set. After the deposition of $0.3 \mathrm{~cm}$ of flat sand, the formation of 8 diapirs was induced by locally eroding the sand over 8 circular areas of $1.5 \mathrm{~cm}$ diameter

The models were prepared with a 0.9-cm-thick basal layer of silicone that covered with a thin layer (less than $1 \mathrm{~mm}$ ) the central structural rise infilling the small graben between the two horsts (figure 13). After the initial deposition of $0.3 \mathrm{~cm}$ of flat sand, the formation of 8 diapirs was induced by locally eroding the sand, over 8 circular areas of $1.5 \mathrm{~cm}$ diameter (figures 13,14). Subsequently, a total thickness of $2.7 \mathrm{~cm}$ of sand simulating the overburden was progressively deposited with a sedimentation rate adapted to the rate of diapiric rise. In particular, when the top of at least one of the eight diapirs reached the surface of the model, the next thin horizontal layer of $0.2 \mathrm{~cm}$ of sand was added to cover the diapir(s) arriving at the surface and all the others that had not completely pierced the overburden. In this way a passive diapiric mechanism was simulated in the experiments. At the end of the experiments (the total duration was about 72 hours), internal sections were cut away after 
the additional coverage of sand on the top and saturation with water. The final geometries of deformation and the mechanism of development of the deformation observed in all the three experiments were very similar.

\subsection{Experimental results}

The results of this set of experiments can be summarized as follows:

a. the nucleation of several smaller diapiric bodies and the contemporary sedimentation of the overburden produced the formation of a wide symmetric anticline with a subvertical axial plane and a hinge zone located over the rigid structural rise of the basement plate, where the basal silicone layer was very thin (figure 15);

b. the flow and withdrawal of the silicone affected the whole basal horizon and not just the areas surrounding the diapirs (rim synclines): the overall flow induced the differential lowering of the entire upper sand layer and the progressive formation of a passive anticline that was much wider than the underlying rigid block;

c. The growth of the anticline was progressive and clearly connected with the extrusion of the silicone putty in the diapirs;

d. at the end of the experiments (figure 15), the average dip of the two limbs of the accommodation passive anticline caused by the generalized flow of silicone towards the diapirs ranged from $1.9^{\circ}$ to $0.5^{\circ}$, progressively decreasing from the base to the top of the sand layers. Moreover, the two limbs of the fold were affected by weak undulations due to the presence of the diapirs;

e. During the experiments, at the surface near some diapiric bodies (figure 16), slight rim synclines were observed, showing a ring-shaped lowering of the surface of less of 1 $\mathrm{mm}$;

f. The average rate of diapir rise was about $0.04 \mathrm{~cm} / \mathrm{hr}\left(4 \times 10^{-7} \mathrm{~m} \mathrm{~s}^{-1}\right)$, but not all the diapiric bodies reached the same vertical development (figure 16), probably due to the different initial conditions (the initial erosion of the first sand layer over 8 circular areas was not exactly the same);

g. Over the graben located in the middle of the rigid structural high, the initial surface erosion induced the growth of a small diapir, which, however, did not reach the surface at the end of the experiments.

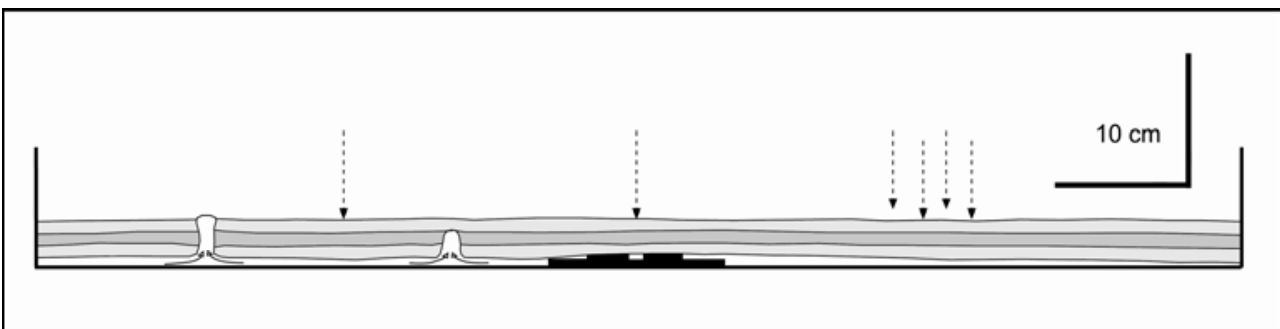

Fig. 15. Sketch of an internal section ( $5 \mathrm{~cm}$ from the removed glass wall) of the experiment. Two diapirs are visible at the left side of the model, while the dotted arrows indicate the position of the other diapirs not visible along this section. The extrusion of the silicone putty in the diapirs caused the formation of the overall passive accommodation anticline, whose limbs have an average dip ranging from $1.9^{\circ}$ to $0.5^{\circ}$ 


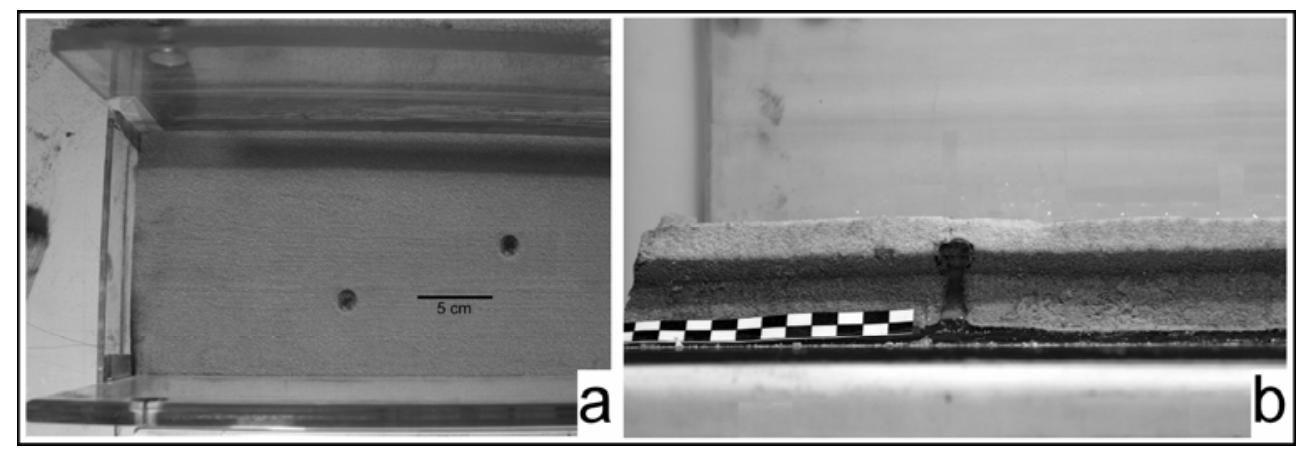

Fig. 16. (a) Top view of two diapirs formed at the final stage of one of the experiments of the second set. A weak lowering of the surface around some diapir (rim synclines), not noticeable in the photograph, was observed during the experiments. (b) Detailed view of a section of a silicone diapir

\subsection{Discussion}

The experiments were focused on the possible regional consequences that a diffuse diapiric rise from a deep discontinuous ductile layer can induce in the overlying sedimentary succession (overburden). In the sand-box models the diapirs pierced the overburden with passive diapirism or downbuilding mechanisms caused by erosion. In fact, they rose continually with respect to surrounding strata and remained exposed while sediments accumulated around them and partially on their roofs. The small diapir formed over the graben located in the middle of the rigid structural high, which did not reach the surface at the end of the experiments suggests that smaller and thinner salt tectonic basins intersecting the basement high under the Qatar-South Fars Arch could have generated small-diameter diapirs (see diapir B in figures 7,10 ). In synthesis, the models show that the extrusion of diapiric bodies from a deep salt layer around a structural high characterized by the absence or extremely reduced thickness of salt could induce the formation of a passive accommodation mega-anticline, whose geometry (extension, dip of the limbs, tightness) is comparable to the Qatar-South Fars warping structure (figure 17). In particular, the experiments performed in a sand-box $90 \mathrm{~cm}$ long (corresponding to more than $300 \mathrm{~km}$ in nature) indicate that the flow and withdrawal of the salt can operate over very great distances, inducing deformation (lowering) of the overburden. From this point of view, taking into account the different volumes involved and the peculiar geometries of the diapirism, the bulk flow of the salt connected to spreading phenomena and salt extrusion (both gravity-induced and with no external tectonic forces applied) is substantially the same: the salt migrates laterally for long distances and accumulates into the rising diapirs. The consequent withdrawal of basal salt causes the lowering of the overburden with respect to the area where salt is absent (the Qatar-South Fars basement high). The very low amount of these differential vertical movements along with the fact that no horizontal stresses are applied (e.g., basement extension, gravitational sliding of the overburden) is probably the reason for the absence of significant deformations in the thick sedimentary succession above the salt. It should be noted that our model (figure 17) does not exclude the repeated basement reactivation of the supposed Qatar-South Fars Arch fault-bounded basement high 
(basement reactivation has been shown in other structures in the region not surrounded by Hormuz salt; see e.g. Wender et al., 1998) but, rather, points out the possible role of basal salt withdrawal as an important control factor in the warping of the sedimentary overburden above pronounced basement structures. With real data (2D seismic sections coverage) it was not possible to compare quantitatively the amount of salt removed from the base of the sedimentary succession with that accumulated into diapirs (and possibly dissolved), that is, to verify salt mass conservation. A good match between these two quantities would point to basal salt withdrawal as a main cause of overburden arching, while a non-correspondence would indicate other processes for overburden deformation. Despite the lack of quantitative assessment of mass conservation in the study area, however, the analogue experiments suggest that the proposed mechanism for the development of the Qatar-South Fars Arch is viable (figure 17).

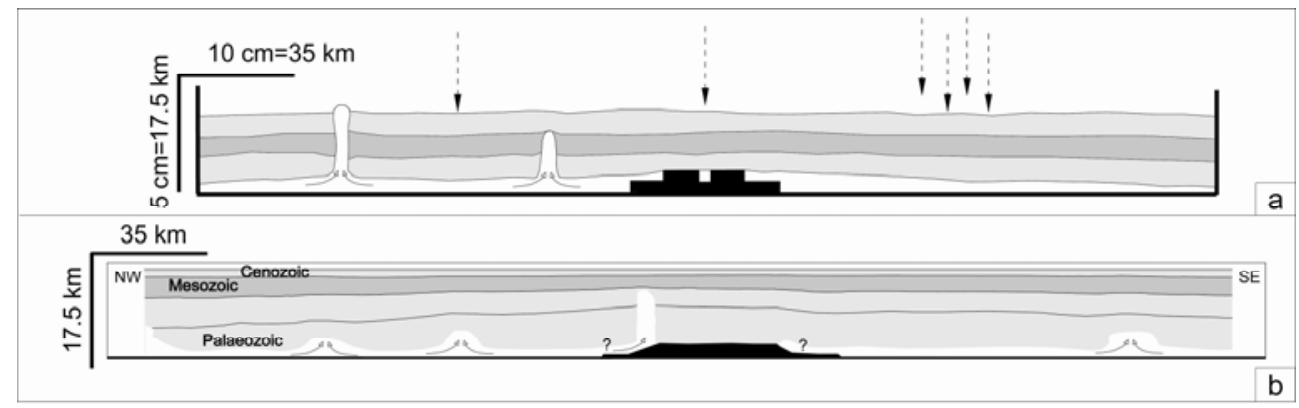

Fig. 17. Comparison between the physical model of figure 17 (a) and the interpreted geologic section (figure 7) across the Qatar-South Fars Arch (b) (vertical exaggeration x2). Both sections show mega-accommodation passive anticlines formed as a result of siliconesalt withdrawal at the sides of a basal structural high. The two anticlines have limbs with a similar average dip and the same extent with respect to the basement high and salt diapirs

\section{Conclusions}

The Qatar-South Fars Arch is the largest structure in the Persian Gulf province. It is a very gentle mega-anticline (more than $100 \mathrm{~km}$ wide and $300 \mathrm{~km}$ long), with a north-northeast to northeast orientation, that developed over a long time-span stretching from the Lower (?) Palaeozoic to the Oligocene. Although the origin of the Qatar-South Fars Arch long-lasting deformation has been explained so far (Edgell, 1992; Konert et al. 2001; Wender et al., 1998) by the repeated tectonic reactivation of Proterozoic faults bordering the basement high at the core of the Arch, no main faults bounding the overlying sedimentary succession of the Qatar-South Fars Arch are detectable in the available seismic sections. In addition to that, the following elements have been highlighted and must be considered.

1. One of the most important features of the Persian Gulf is the presence of several diapiric bodies that locally deform the sea bed or form islands (Edgell, 1996; Nasir et al., 2008). Salt diapirism created numerous elongate or circular (especially in the Southern Gulf Salt basin) salt domes. However, diapiric phenomena are practically absent over the top of the Qatar-South Fars Arch, possibly due to the lack or reduced (diapirism directly adjacent to the horst) thickness of the Hormuz Formation on an emerged 
basement horst block during the deposition of the evaporites (late Proterozoic-early Palaeozoic).

2. The height difference between the crest and trough of the Qatar-South Fars anticline seems approximately compatible with the Hormuz Formation thickness (probably more than $2500 \mathrm{~m})$.

3. A tectonic reactivation of the basement high coring the Qatar-South Fars Arch is hardly compatible with a north to northeast direction of the arch. In fact, the major episodes of compression and extension had roughly a northeast- southwest axis, which was perpendicular to the northwest-southeast margin of the Arabian plate and therefore not congruent with the development of the Qatar-South Fars Arch anticline.

All these elements and the widespread salt mobilization in the Gulf led us to think that the arching of the sedimentary cover over a basement high during several phases in the Phanerozoic might have been linked to the lateral withdrawal of the deep Infracambrian Hormuz salt, continuously feeding the several salt plugs and diapirs occurring to the northwest and southeast of the arch.

Drape folding of the succession by salt withdrawal into vertically rising diapirs has been investigated with physical models. The experimental results suggest that the mobilization of a discontinuous basal Hormuz salt layer may have induced the passive folding of the overlying sedimentary succession over a "rigid" Qatar-South Fars Arch core (a basement high or a non-evaporitic rock unit). In other words, the Qatar-South Fars Arch could be a mega-accommodation anticline due to salt withdrawal of an unevenly distributed salt layer. The proposed salt-controlled evolution of the Qatar-South Fars Arch could account for its continuous, long-lasting evolution in a basically stable tectonic setting, where tectonic movements have been limited to periodic salt diapir growth and reactivation (Carruba et al., 2007).

\section{Acknowledgments}

The authors are grateful to NIOC and EDISON managements for granting to publish this study. The ideas expressed in this article are those of the authors and may not reflect any official position of the two companies. Many thanks also to the reviewers, who substantially helped improve the original manuscript.

\section{References}

Al Husseini, M.I. (2000). Origin of the Arabian plate structures: Amar collision and Najd rift. GeoArabia, Vol. 5, No. 4, pp. 527-542

Al Husseini, M.I. (2008). Middle East Geological Time Scale 2008. GeoArabia, Vol. 13, No. 4

Ala, M.A. (1974). Salt diapirism in Southern Iran. American Association of Petroleum Geologists Bulletin, Vol. 58, No. 9, (September 1974), pp. 1758-1770

Alsharhan, A.S., \& Nairn, A.E.M. (1994). Geology and hydrocarbon habitat in the Arabian Basin: the Mesozoic of the State of Qatar. Geologie en Mijnbouw, Vol. 72, pp. 265-294

Alsharhan, A.S., \& Nairn, A.E.M. (1997). Sedimentary basins and petroleum geology of the Middle East, Elsevier, Amsterdam

Beydoun, Z.R. (1991). Arabian Plate Hydrocarbon Geology and Potential - A Plate Tectonic Approach. American Association of Petroleum Geologists Studies in Geology, Vol. 33 
Brun, J.P., \& Fort, X. (2004). Compressional salt tectonics (Angolan Margin). Tectonophysics, Vol. 382, No. 3-4, (April 2004), pp. 129-150

Brun, J.P., \& Mauduit, T. (2008). Rollovers in salt tectonics: the inadequacy of the listric fault model. Tectonophysics, Vol. 457, No. 1-2, (September 2008), pp. 1-11

Bruthans, J., Filippi, M., Geršl, M., Zare, M., Melková, J., Pazdur, A., \& Bosák, P. (2006). Holocene marine terraces on two salt diapirs in Persian Gulf (Iran): age, depositional history and uplift rates. Journal of Quaternary Science, Vol.21, No. 8, (December 2006), pp. 843-857

Byerlee, J.D. (1978). Friction of Rocks, In: Pure and Applied Geophysics. Contribution to Current Research in Geophysics, J.D. Byerlee, \& M. Wyss, (Eds), pp. 615-626, Birkhäuser Verlag, Basel

Carruba, S., Bertozzi, G., Perotti, C.R., \& Rinaldi, M. (2007). Alcuni aspetti del diapirismo salino nel Golfo Persico. Rendiconti della Società Geologica Italiana, Vol. 4, pp. 188-190

Cobbold, P.R., Rossello, E., \& Vendeville, B. (1989). Some experiments on interacting sedimentation and deformation above salt horizons. Bulletin de la Société Géologique de France, Vol. 3, pp. 453-460

Cobbold, P.R., \& Szatmari, P. (1991). Radial gravitational gliding on passive margins. Tectonophysics, Vol. 188, No. 3-4, (March 1991), pp. 249-289

Cotton, J., \& Koyi, H. (2000). Modeling of thrust front above ductile and frictional detachments: application to structures in the Salt Range and Potwar Plateau, Pakistan. Geological Society of America Bulletin, Vol. 112, No. 3, (March 2000), pp. 351363

Dill, H.G., Nasir, S., \& Al-Saad, H. (2003). Lithological and structural evolution of the northern sector of the Dukhan Anticline, Qatar, during the early Tertiary: with special reference to bounding surfaces of sequence stratigraphical relevance. Geoarabia, Vol. 82, pp. 201-226

Edgell, H.S. (1992). Basement tectonics of Saudi Arabia as related to oil field structures, In: Basement tectonics 9, M.H. Rickard, \& al., (Eds), pp. 169-193, Kluwer Academic Publishers, Dordrecht

Edgell, H.S. (1996). Salt tectonism in the Persian Gulf, In: Salt tectonics, G.I. Alsop, D.J. Blundell, \& I. Davison, (Eds), pp. 129-151, Geological Society of London Special Publication No. 100, The Geological Society Publishing House, Bath

Faugère, E., \& Brun, J.P. (1984). Modélisation expèrimentale de la distension continentale. Comptes Rendus Académie des Sciences Paris, Vol. 299, pp. 365-370

Fort, X., Brun, J.P., \& Chauvel, F. (2004a). Salt tectonics on the Angolan margin, synsedimentary deformation processes. American Association of Petroleum Geologists Bulletin, Vol. 88, No. 11, (November 2004), pp. 1523-1544

Fort, X., Brun, J.P., \& Chauvel, F. (2004b). Contraction induced by block rotation above salt. Marine and Petroleum Geology, Vol. 21, No. 10, (December 2004), pp. 1281-1294

Gaullier, V., Brun, J.P., Guerin, G., \& Lecanu, H. (1993). Raft tectonics: the effects of residual topography below a salt décollement. Tectonophysics, Vol. 228, No. 3-4, (December 1993), pp. 363-381

Ge H., Jackson M.P.A., \& Vendeville, B. (1997). Kinematics and dynamics of salt tectonics driven by progradation. American Association of Petroleum Geologists Bulletin, Vol. 81, No. 3, (March 1997), pp. 398-423 
Higgins, R.I., \& Harris, L.B. (1997). The effects of cover composition on extensional faulting above re-activated basement faults: results from analogue modelling. Journal of Structural Geology, Vol. 19, No. 1 (January 1997), pp. 89-98

Hubbert, M.K. (1937). Theory of scale models as applied to the study of geologic structures. Geological Society of America Bulletin, Vol. 48, No. 10, (October 1937), pp.1459-1520

Hughes, M., \& Davison, I. (1993). Geometry and growth kinematics of salt pillows in the southern North Sea. Tectonophysics, Vol. 228, No. 3-4, (December 1993), pp. 239-254

Husseini, M.I. (1988). The Arabian Infracambrian extensional system. Tectonophysics, Vol. 148, No. 1-2, (April 1988), pp. 93-103

Johnson, P.R., \& Stewart, I.C.F. (1995). Magnetically inferred basement structure in central Saudi Arabia. Tectonophysics, Vol. 245, No. 1-2, (May 1995), pp. 37-52

Kent, P.E. (1958). Recent studies of South Persian salt plugs. American Association of Petroleum Geologists Bulletin, Vol. 42, No. 12, (December 1958), pp. 2951-2972

Konert, G., Afifi, A.M., Al-Hajri, S.A., \& Droste, H.J. (2001). Paleozoic stratigraphy and hydrocarbon habitat of the Arabian Plate. GeoArabia, Vol. 6, No. 3, pp. 407-442

Koyi, H., \& Petersen, K. (1993). Influence of basement faults on the development of salt structures in the Danish basin. Marine and Petroleum Geology, Vol. 10, No. 2 (April 1993), pp. 82-94

Mauduit, T., Gaullier. V., Guérin, G., \& Brun, J.P. (1997a). On the asymmetry of turtle back growth anticlines. Marine and Petroleum Geology, Vol. 14, No. 7-8, (NovemberDecember 1997), pp. 763-771

Mauduit, T., Guérin, G., Brun, J.P., \& Lecanu, H. (1997b). Raft tectonics, the effects of basal slope value and sedimentation rate on progressive deformation. Journal of Structural Geology, Vol. 19, No. 9, (September 1997), pp. 1219-1230

Mauduit, T., \& Brun, J.P. (1998). Development of growth fault/rollover systems. Journal of Geophysical Research, Vol. 103, No. B8, pp. 18119-18130

Maurin, J.C. (1995). Drapage et décollement des series jurassiques sur la faille de détachement majeure du rift rhénan sud: implications sur la géométrie des depots syn-rifts oligocenes. Comptes Rendus Académie des Sciences Paris, Vol. 321, pp. 10251032

McClay, K.R., Dooley, T., \& Lewis, G. (1998). Analog modeling of progradational delta systems. Geology, Vol. 26, No. 9, (September 1998), pp. 771-774

Nalpas, T., \& Brun, J.P. (1993). Salt flow and diapirism related to extension at crustal scale. Tectonophysics, Vol. 228, No. 3-4, (December 1993), pp. 349-362

Nasir, S., Al-Saad, H., Alsayigh, A., \& Weidlich, O. (2008). Geology and petrology of the Hormuz dolomite, Infra-Cambrian: Implications for the formation of the salt-cored Halul and Shraouh islands, Offshore, State of Qatar. Journal of Asian Earth Sciences, Vol. 33, No. 5-6, (August 2008), pp. 353-365

Nikishin, A.M., Cloetingh, S., Lobkovsky, L.I., Burov, E.B., Lankreijer, A.C. (1993). Continental lithosphere folding in Central Asia (part I): constraints from geological observations. Tectonophysics, Vol. 226, No. 1-4, (November 1993), pp. 59-72

Pollastro, R.M. (2003). Total petroleum systems of the Paleozoic and Jurassic, Greater Ghawar Uplift and adjoining provinces of Central Saudi Arabia and Northern Arabia-Persian Gulf. United States Geological Survey Bulletin, Vol. 2202-H, Available from http://pubs.usgs.gov/bul/b2202-h/ 
Qatar General Petroleum Corporation (QGPC), Amoco Qatar Petroleum Company (AQPC) (1991). Dukhan Field - Arabian Platform, In: Structural traps V, Treatise of Petroleum Geology, Atlas of Oil and Gas Fields, N.H. Foster, \& E.A. Beaumont (Eds), pp. 103-120, American Association of Petroleum Geologists, Tulsa

Ramberg, H. (1981). Gravity, Deformation and Earth's Crust, (second edition), Elsevier, New York

Sharland, P.R., Archer, R., Casey, D.M., Davies, R.B., Hall, S.H., Heward, A.P., Horbury, A.D., Simmons, M.D. (2001). Arabian Plate sequence stratigraphy. GeoArabia Special Publication No.2, Gulf PetroLink, Manama

Stampfli, G.M., \& Borel, G.D. (2004). The TRANSMED Transects in Space and Time: Constraints on the Paleotectonic Evolution of the Mediterranean Domain, In: The TRANSMED Atlas: the Mediterranean Region from Crust to Mantle, W. Cavazza, F. Roure, W. Spakman, G.M. Stampfli, P. Ziegler (Eds.), pp. 53-80, Springer-Verlag, Berlin Heidelberg

Sugden, W. (1962). Structural analysis and geometrical prediction for change of form with depth of some Arabian plains-type folds. American Association of Petroleum Geologists Bulletin, Vol. 46, No. 12 (December 1962), pp. 2213-2228

Talbot, C.J., \& Alavi, M. (1996). The past of a future syntaxis across the Zagros. In: Salt Tectonics, G.I. Alsop, D.J. Blundell, \& I. Davison (Eds.), pp. 89-109, Geological Society of London Special Publication No. 100, The Geological Society Publishing House, Bath

Talbot, C., Aftabi, P., Chemia, Z. (2009). Potash in a salt mushroom at Hormoz Island, Hormoz Strait, Iran. Ore Geology Reviews, Vol. 35, No. 3-4, (June 2009), pp. 317-332

van Keken, P.E., Spiers, C.J., Van den Berg, A.P., Muyzert, E.J. (1993). The effective viscosity of rocksalt: implementation of steady-state creep laws in numerical models of salt diapirism. Tectonophysics, Vol. 225, No. 4, (October 1993), pp. 457-476

Vendeville, B., \& Cobbold, P.R. (1987). Glissements gravitaires synsédimentaires et failles normales listriques: modèles expérimentaux. Comptes Rendus Académie des Sciences Paris, Vol. 305, pp. 1313-1319

Vendeville, B., Cobbold, P.R., Davy, P., Brun, J.P., \& Choukroune, P. (1987). Physical models of extensional tectonics at various scales. In: Continental Extensional Tectonics, M. Coward, J.F. Dewey, \& P.L. Hancock (Eds.), pp. 95-107, Geological Society of London Special Publication No. 28, Blackwell Scientific Publication, Oxford

Vendeville, B., \& Jackson, M.P.A. (1992a). The rise of diapirs during thin skinned extension. Marine and Petroleum Geology, Vol 9, No. 4, (August 1992), pp. 331-353

Vendeville, B., \& Jackson, M.P.A. (1992b). The fall of diapirs during thin skinned extension. Marine and Petroleum Geology, Vol. 9, No. 4, (August 1992), pp. 354-371

Vendeville, B., Hongxing, G., \& Jackson, M.P.A. (1995). Scale models of salt tectonics during basement-involved extension. Petroleum Geoscience, Vol. 1, No. 2, (May 1995), pp. 179-183

Weijermars, R. (1986). Flow behavior and physical chemistry of bouncing putties and related polymers in view of tectonic laboratory applications. Tectonophysics, Vol. 124, No. 34, (April 1986), pp. 325-358

Weijermars, R., Jackson, M.P.A., \& Vendeville, B. (1993). Rheological and tectonic modeling of salt provinces. Tectonophysics, Vol. 217, No. 1-2, (January 1993), pp. 143-174 
Wender, L.E., Bryant, J.W., Dickens, M.F., Neville, A.S., \& Al-Moqbel, A.M. (1998). Paleozoic (Pre-Khuff) Hydrocarbon Geology of the Ghawar Area, Eastern Saudi Arabia. GeoArabia, Vol. 3, pp. 273-302

Withjack, M.O., Meisling, K., \& Russel, L. (1989). Forced folding and basement-detached normal faulting in the Haltenbanken area, offshore Norway. In: Extensional tectonics and stratigraphy of the North Atlantic margins, pp. 567-575, A.J. Tankard, \& H.R. Balkwill (Eds), American Association of Petroleum Geologists Memoir No.46, Tulsa

Withjack, M.O., Olson, J., \& Peterson, E. (1990). Experimental models of extensional forced folds. American Association of Petroleum Geologists Bulletin, Vol. 74, No. 7, (July 1990), pp. 1038-1054

Withjack, M.O., \& Callaway, S. (2000). Active Normal Faulting Beneath a Salt Layer: An Experimental Study of Deformation Patterns in the Cover Sequence. American Association of Petroleum Geologists Bulletin, Vol. 84, No. 5, (May 2000), pp. 627-651

Ziegler, M.A. (2001). Late Permian to Holocene Paleofacies Evolution of the Arabian Plate and its Hydrocarbon Occurrences. GeoArabia, Vol. 6, pp. 445-504 


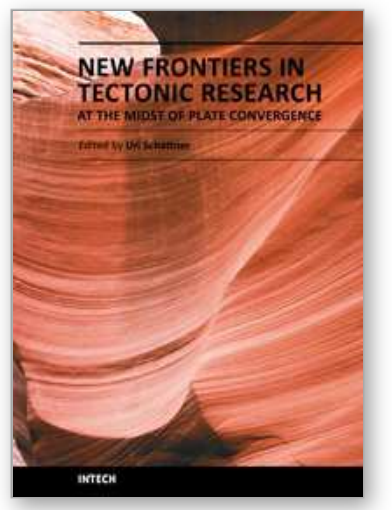

\section{New Frontiers in Tectonic Research - At the Midst of Plate Convergence}

Edited by Dr. Uri Schattner

ISBN 978-953-307-594-5

Hard cover, 352 pages

Publisher InTech

Published online 09, August, 2011

Published in print edition August, 2011

Ocean closure involves a variety of converging tectonic processes that reshape shrinking basins, their adjacent margins and the entire earth underneath. Following continental breakup, margin formation and sediment accumulation, tectonics normally relaxes and the margins become passive for millions of years. However, when final convergence is at the gate, the passive days of any ocean and its margins are over or soon will be. The fate of the Mediterranean and Persian Gulf is seemingly known beforehand, as they are nestled in the midst of Africa-Arabia plate convergence with Eurasia. Over millions of years through the Cenozoic era they progressively shriveled, leaving only a glimpse of the Tethys Ocean. Eventually, the basins will adhere to the Alpine-Himalaya orogen and dissipate. This book focuses on a unique stage in the ocean closure process, when significant convergence already induced major deformations, yet the inter-plate basins and margins still record the geological history.

\section{How to reference}

In order to correctly reference this scholarly work, feel free to copy and paste the following:

C.R. Perotti, S. Carruba, M. Rinaldi, G. Bertozzi, L. Feltre and M. Rahimi (2011). The Qatar-South Fars Arch Development (Arabian Platform, Persian Gulf): Insights from Seismic Interpretation and Analogue Modelling, New Frontiers in Tectonic Research - At the Midst of Plate Convergence, Dr. Uri Schattner (Ed.), ISBN: 978953-307-594-5, InTech, Available from: http://www.intechopen.com/books/new-frontiers-in-tectonic-researchat-the-midst-of-plate-convergence/the-qatar-south-fars-arch-development-arabian-platform-persian-gulfinsights-from-seismic-interpreta

\section{INTECH}

open science | open minds

\section{InTech Europe}

University Campus STeP Ri

Slavka Krautzeka 83/A

51000 Rijeka, Croatia

Phone: +385 (51) 770447

Fax: +385 (51) 686166

www.intechopen.com

\section{InTech China}

Unit 405, Office Block, Hotel Equatorial Shanghai

No.65, Yan An Road (West), Shanghai, 200040, China 中国上海市延安西路65号上海国际贵都大饭店办公楼 405 单元

Phone: $+86-21-62489820$

Fax: +86-21-62489821 
(C) 2011 The Author(s). Licensee IntechOpen. This chapter is distributed under the terms of the Creative Commons Attribution-NonCommercialShareAlike-3.0 License, which permits use, distribution and reproduction for non-commercial purposes, provided the original is properly cited and derivative works building on this content are distributed under the same license. 